Plant Production Science

http:/www.journals.zu.edu.eg/journalDisplay.aspx?Journalld=1\&queryType=Master

\title{
STABILITY ANALYSIS OF BARLEY GENOTYPES UNDER DIFFERENT WATER STRESS LEVELS
}

\author{
Fatma M.A. Megahed ${ }^{2 *}$, A.A. El-Khawaga ${ }^{1}$, M.M.A. Ali $^{1}$ and A.I. A. Hassan ${ }^{2}$ \\ 1. Agron. Dept., Fac. Agric., Zagazig Univ., Egypt \\ 2. Genet. Res. Dept., Des. Res. Cent., Cairo, Egypt
}

Received: 20/05/2018 ; Accepted: 02/07/2018

\begin{abstract}
Water deficit is the main yield-limiting factor in Egypt and overall the world. Thus the main objective from this work was to evaluate eighteen barley genotypes differed in their genetic makeup under six varied environments which are the combination between, two growing seasons (2013/2014 and 2014/2015) and three water irrigation levels $\left(800,1100\right.$ and $1400 \mathrm{~m}^{3} / \mathrm{fad}$.) as severe stress, moderate stress and adequate, respectively in newly reclaimed sandy soil of South El-Qantara Shark, Ismailia, Egypt, for days to 50\% heading, flag leaf area, plant height, 1000-grain weight, biological yield and grain yield. The combined analyses of variance and the mean square of joint regression analysis of variance revealed significant differences among genotypes $(G)$, environments (E) and the $G \times E$ interaction for all the traits. Environment + Genotype $\times$ Environment $(E+G \times E)$, mean squares due to environment (linear) and linear interaction $(\mathrm{G} \times \mathrm{E}$ linear) had highly significant effects for all characters. Severe and moderate water stress levels were significantly reduced all studied traits except 1000-grain weight for all barley genotypes than adequate water supply treatment. Grain yield reduced in the $1^{\text {st }}$ year by an average of $25.67 \%$ and $13.44 \%$ and in the $2^{\text {nd }}$ year by an average of $26.82 \%$ and $12.67 \%$ under $1^{\text {st }}$ and $2^{\text {nd }}$ irrigation levels, respectively, compared with the $3^{\text {rd }}$ level. Phenotypic stability parameters showed that barely genotypes, Line 9, Rihane 3 and Line 11 were highly adapted to favorable environments for days to $50 \%$ heading; Line 6, Line 5 and Giza 2000 for plant height; Giza 126 for flag leaf area; Line 1, Line 11 and Rihane 3 for 1000-grain weight; Line 9, Line 7 and Line 2 for biological yield and Line 6, Line 9 and line 10 for grain yield. Genotypic stability parameters indicated that barley genotypes Line 11 and Giza 2000 was highly adapted to favorable environments for days to $50 \%$ heading; Line 2 for plant height, 1000 -grain weight and biological yield; California mariout, Giza 123, Line 4, Line 6 and Line 7 for grain yield. The additive main effects and multiplicative interaction (AMMI) analysis of variance showed highly significant difference among genotypes, environments, G $\times$ E, IPCA1 and IPCA2. AMMI stability value (ASV) and GE biplot revealed that, the most desired and stable genotypes were Line 1, Giza 123, California mariout, Line 8 and Line 6 for grain yield. According to genotype plus genotype $\times$ environment (GGE) biplots, the ideal genotype was Line 9 for days to $50 \%$ heading; Line 6 for plant height; Line 11 for flag leaf area; Line 1 for 1000-grain weight; Line 9 for biological yield and Line 6 for grain yield.
\end{abstract}

Key words: Barley, genotype $\times$ environment, phenotypic and genotypic stability, AMMI, water stress.

\section{INTRODUCTION}

Barley (Hordeum vulgare L.) is predominant to be the most drought tolerant of the small grain cereal crops (barley, durum wheat and bread wheat) and is a major crop in Middle East and North Africa countries, because it is the

\footnotetext{
* Corresponding author: Tel. : +201026367346

E-mail address: abd_Lhamed@yahoo.com
}

predominant crop lower $300 \mathrm{~mm}$ of annual rainfall. In Mediterranean areas barley is primarily grown as animal feed and both grain and straw yields are used.

In Egypt, barley is the main cereal crop grown after wheat in winter season on a large scale in the newly reclaimed land, in the low 
rainfall northern coastal area $(100-200 \mathrm{~mm}$ annual rainfall) and in regions affected by salinity or where fresh water supplies are limited resource. It is grown in both rainfed and irrigated conditions, though in the more favorable irrigated soils of the Nile Valley barley gives way to more valuable crops. The total area to worldwide in 2016 reached about 46.9 million hectares gave total production 141.3 million tons with average 3.01 tons/ha. Meanwhile, in Egypt, the total area was about 77.6 thousand hectares gave total production 120.1 thousand tons with average 1.55 tons/ha (FAOSTAT, 2018). Breeding barley objectives in Egypt include short life cycles, high grain yields, straw yield, grain quality, drought, salt and heat tolerance, and resistance to pests and diseases. Tall, six-row lines predominate, but there are active breeding programmes and trialing of two row types (Forster el al., 2004).

In newly reclaimed sandy soils, fertilization, irrigation and their interaction are the most important factors for increasing grain yield production (Shaaban, 2006; Ali, 2017). Drought is the main yield-limiting factor in Mediterranean region, therefore significant areas are watered, while the irrigation water is limited (Forster $\boldsymbol{e t}$ al., 2004). Water deficit is one of the major abiotic stresses that severely effects on barley production, it will increase frequency with climate changes. Selection of drought tolerance barley genotypes through agronomic and physiological traits is suitable indicators to increase crop yield in breeding program, and it is major goal of plant breeder nowadays.

Abiotic stresses including water stress can significantly decrease crop yields and limit the latitudes and soils on which commercially essential species can be cultivated (Blum, 1985). The seriousness of drought stress depends on its timing, duration and intensity (Serraj et al., 2005). Drought stress tolerance is a complex inherited trait controlled by several genetic loci and is often confounded by changes in plants phenology (Fleury et al., 2010). Water deficit happens when water potentials in the rhizosphere are sufficiently negative to decrease water availability to sub-optimal levels for crop growth and development (Diab et al., 2004). The combination of continued impact of drought and high temperature impairs the photosynthesis during the day-time and increases the surface temperatures in the night, which in turn increase the photo respiratory losses and thus the productivity (Mir et al., 2012).

Water deficit stress during barely grainfilling period lessened the net photosynthetic rate of the flag leaf (Sánchez-Díaz et al., 2002). Thus, the main photosynthetic organs of barley are the flag leaf and ear to provide assimilates for grain filling, mainly where drought is encountered at the completion of the plants' life cycle (Blum, 1985 ; Bort et al., 1994).

Drought stress decreases grain yield of barley genotypes through negative influence on yield components i.e. No. of plants/unit area, No. of spikes and grains per plant or unit area and 1000-grain weight, which are determined at different stages of plant development (Samarah $\boldsymbol{e t}$ al., 2009; Hossain et al., 2012; Haddadin, 2015; Al-Ajlouni et al., 2016) and Early flowering barely genotypes were better performance as reflected in higher yield compared with late flowering genotypes (Al-Ajlouni et al., 2016). Baum et al. (2003) reported that tillering was an important trait for phenotypic plasticity to drought. A number of researchers have reported that drought tolerant genotypes perform high productivity under both well-watered and drought environments (Samarah et al., 2009; Sharafi et al., 2011; Haddadin, 2015) and can be used as parents in breeding programmes for improvement of drought tolerance in other barley cultivars (Haddadin, 2015). Selection of different cereal crops genotypes under drought stress conditions is one of the main tasks of plant breeders for exploiting the genetic variations to improve the stress-tolerant cultivars (Ali, 2016; Ali and Abdul-Hamid, 2017).

The evaluation of barely genotypes in different environments is often performed to select the best varieties for an environment. The analysis and interpretation of genotype-environment interaction (GEI) range from simple analysis of variance to more specific analyses of genotype performance, from the univariate linear regression analysis of Finlay and Wilkinson (1963) and Eberhart and Russell (1966), genotypic stability (Tai, 1971) to the multivariate AMMI (Zobel et al., 1988) and GGE biplot (Yan, 2001). The AMMI has proven useful for understanding complex genotype $\times$ environment interactions. The AMMI Stability 
value (ASV) proposed by Purchase (1997) and Purchase et al. (2000). Biplots of the first two principal components were used to illustrate these relationships (Gabriel, 1971; Kempton, 1984).

The major objectives of the current study were to evaluate response of eighteen barely genotypes under different water supply levels over two years at newly reclaimed sandy soils and study partitioning the genotype by environment interaction to its stability parameters, using joint regression, genotypic stability, the AMMI and the sites regression (SREG) methods.

\section{MATERIALS AND METHODS}

\section{Field Region and Barley Genotypes}

Three separate trials were grown side by side with $12 \mathrm{~m}$ apart on all sides, in the South ElQantara Shark Agric. Res. Station, Barley Research Department, Field Crops Research Institute; Agricultural Research Center, Ismailia governorate condition, during two winter seasons; 2013/2014 and 2014/2015.

Eighteen six-row genotypes of barley (Hordeum vulgare L.), which were represent in thirteen promising strains and five local and introduced varieties i.e., Giza 123, Giza 126, Giza 2000, Rihane 3 and California mariout were selected from barley program breeding, ARC, based on their tolerance to drought stress. The pedigree of the tested barley genotypes are presented in Table 1.

\section{Field Experiments}

Field experiments were carried out in six environments which were the combination between, two years and three water regimes $\left(800,1100\right.$ and $1400 \mathrm{~m}^{3} / \mathrm{fad}$. as severe stress, moderate stress and adequate, respectively). Quantities of water irrigation were adjusted by a water counter for all irrigation treatments, sprinkler irrigation system was used.

The experimental layout was a factorial randomized complete block design with three replications. In each environment, the plot area was $6 \mathrm{~m}^{2}$ included 10 rows, $3 \mathrm{~m}$ long and $20 \mathrm{~cm}$ apart. Seeds of the eighteen tested barley genotypes were hand drilled at sowing rate of 50 $\mathrm{kg}$ grains/fad., for all tested barley genotypes. Sowing date was on the first week of December in the two seasons.

The experimental field was well prepared through two perpendicular, ploughs, harrowing and good leveling. Recommended $\mathrm{P}$ and $\mathrm{K}$ fertilizers were added at the rate of $150 \mathrm{~kg} /$ fad., calcium super phosphate $\left(15.5 \% \mathrm{P}_{2} \mathrm{O}_{5}\right)$ and 50 $\mathrm{kg} /$ fad., potassium sulphate $\left(48 \% \mathrm{~K}_{2} \mathrm{O}\right)$ during seed bed preparation for phosphate fertilizer and after 20 and 40 days from sowing for potassium fertilizer in two equal doses. Recommended $\mathrm{N}$ fertilizers was applied at the rate of $60 \mathrm{~kg} \mathrm{~N} /$ fad., in the form of ammonium nitrate $33.5 \%$ $\mathrm{N}$ ) in five equal doses, the first dose was added 14 days after sowing while the remainders were applied 10 days intervals. All other cultural practices for barley were applied as local recommendations in the region.

The soil of the experimentation site was sandy texture and the mechanical and chemical analyses of the soil and the water in the experimental sites are given in Tables 2, 3, 4 and 5 , representative soil sample used in the experimental soil were determined before preparation according to Jackson (1973).

\section{Water Supply Treatments}

Three water regimes were used in this study as followed: The $1^{\text {st }}$ irrigation treatment, $\mathrm{S}$ (severe stress): All plots received a total amount of water $800 \mathrm{~m}^{3} / \mathrm{fad}$. This amount was given into 2 irrigations/week with $20 \mathrm{~m}^{3}$ for each irrigation from seedling stage until heading stage and then $30 \mathrm{~m}^{3}$ from heading stage to maturity stage. The $2^{\text {nd }}$ irrigation treatment, $M$ (moderate stress): All plots received a total amount of water $1100 \mathrm{~m}^{3} /$ fad. This amount was given into 2 irrigations/ week with $27 \mathrm{~m}^{3}$ for each irrigation from seedling stage to heading stage and watering with $37 \mathrm{~m}^{3}$ from heading stage to maturity stage. The $3^{\text {rd }}$ irrigation treatment, $\mathrm{N}$ (optimum or adequate water supply): All plots received a total amount of water $1400 \mathrm{~m}^{3} / \mathrm{fad}$. This amount was given into 2 irrigations/week with $34 \mathrm{~m}^{3}$ for each irrigation from seedling stage until heading stage and then $44 \mathrm{~m}^{3}$ from heading stage to maturity stage. 
Table 1. The origin and pedigree of the eighteen barley genotypes

\begin{tabular}{|c|c|c|c|}
\hline No. & Name & Pedigree & Origin \\
\hline$\overline{\text { G1 }}$ & California mariout & Land race & Egypt \\
\hline G2 & Line 1 & Fedora/Express/Saida & ICARDA \\
\hline G3 & Line 2 & $\begin{array}{l}\text { Arar/PI386540/Giza121/Pue/4/Deiralla106/Cel/3/Bco } \\
\text { Mr/Mza// Apm/5106. }\end{array}$ & ICARDA \\
\hline G4 & Line 3 & $\begin{array}{l}\text { Alanda/5/Aths/4/Pro/Toll//Cer*2/Toll/3//5/06/6/Baca"S"/3/ } \\
\text { AC253//Clo8887/Clo5761 }\end{array}$ & ICARDA \\
\hline G5 & Giza 123 & Giza 117/ FAO86 & Egypt \\
\hline G6 & Line 4 & $\begin{array}{l}\text { PETUNIA2 / 3GLORIA-BAR / COME // ESPERANZA } \\
\text { /4/... CBSS99M00349T-F-3M-1Y-IM-IY-IM-0M }\end{array}$ & ICARDA \\
\hline G7 & Line 5 & $\begin{array}{l}\text { CHENG DU } 105 \text { /4/ EGYPT4 / TERAN78 // P.STOO } \\
/ 3 / \ldots \text { CBSS00Y00236T-E-0Y-0M-2Y-0M }\end{array}$ & ICARDA \\
\hline G8 & Line 6 & $\begin{array}{l}\text { TOCTE /3/CHAMICO/TOCTE//CONGONA/4/ LIGNEE } \\
\text { 527/ CBSS99M00468T-H-1M-1Y-1M-1Y-0M }\end{array}$ & ICARDA \\
\hline G9 & Line 7 & $\begin{array}{l}\text { GLORIA-BAR / COME // LIGNEE640 /3/ S.P-B/4/SLLO } \\
\text { /5/CBSS99M00429T-L-1M-1Y-1M-1Y-0M }\end{array}$ & ICARDA \\
\hline G10 & Line 8 & $\begin{array}{l}\text { BBSC/CONGONA//BLLU/3/CIRU } \\
\text { CBSS00Y00225T-C-0Y-0M-2Y-1M-0M }\end{array}$ & ICARDA \\
\hline G11 & Line 9 & $\begin{array}{l}\text { FORRAJERA KLEIN/DELO CBSW98W00054S-8Y-2M- } \\
\text { 1Y-2M-1Y-0M }\end{array}$ & ICARDA \\
\hline G12 & Line 10 & $\begin{array}{l}\text { ALPHA-BAR/DURRA//CORACLE/3/ALELI/4/ } \\
\text { CBSS99M00317T-AH-2M-1Y-1M-1Y-0M }\end{array}$ & ICARDA \\
\hline G13 & Line 11 & $\begin{array}{l}\text { JANE/TOCTE//PEREGRIN } \quad \text { CBSS00Y00402T-AH-0Y- } \\
\text { 0M-2Y-0M }\end{array}$ & ICARDA \\
\hline G14 & Line 12 & $\begin{array}{l}\text { PETUNIA2 /3/ TOCTE / TOOCTE / TOCTE // BERROS } \\
\text { /4/ PENCOO / CBSS00Y00475T-O-0Y-0M-2Y-0M }\end{array}$ & ICARDA \\
\hline G15 & Line 13 & $\begin{array}{l}\text { PETUNIA2 /6/ ALPHA-BAR / DURRA // CORACLE /3/ } \\
\text { CBSS00Y00446D-F-0Y-0M-1Y-0M }\end{array}$ & ICARDA \\
\hline G16 & Rihane 3 & As 46//Avt/Aths & ICARDA \\
\hline G17 & Giza 2000 & Giza117/Bahteem52// Giza118/ FAO86 / 3/ Baladi16/ Gem & Egypt \\
\hline G18 & Giza 126 & Baladi-Bahteem/SD729-por12762-Bc & Egypt \\
\hline
\end{tabular}

Table 2. Some physical analyses in the experimental soils

\begin{tabular}{|c|c|c|c|c|c|c|c|c|c|c|c|}
\hline \multirow{2}{*}{$\begin{array}{c}\text { Parcel } \\
\text { No. }\end{array}$} & \multirow{2}{*}{$\begin{array}{c}\text { Depth } \\
(\mathrm{cm})\end{array}$} & \multirow{2}{*}{$\begin{array}{c}\mathrm{CaCo}_{3} \\
(\%)\end{array}$} & \multirow{2}{*}{$\begin{array}{l}\text { SP } \\
(\%)\end{array}$} & \multirow{2}{*}{$\begin{array}{c}\text { Gravel } \\
(\%)\end{array}$} & \multicolumn{6}{|c|}{ Particle size distribution (\%) } & \multirow{2}{*}{$\begin{array}{c}\text { Texture } \\
\text { class }\end{array}$} \\
\hline & & & & & $\begin{array}{c}2-1 \\
m m\end{array}$ & $\begin{array}{c}1-0.5 \\
\mathrm{~mm}\end{array}$ & $\begin{array}{c}0.50 \\
0.25 \mathrm{~mm}\end{array}$ & $\begin{array}{c}0.25 \\
0.125 \mathrm{~mm}\end{array}$ & $\begin{array}{c}0.125- \\
0.063 \mathrm{~mm}\end{array}$ & $\begin{array}{c}<0.063 \\
\mathrm{~mm}\end{array}$ & \\
\hline \multirow[t]{4}{*}{6} & $0-15$ & 0.37 & 17.0 & 0.0 & 6.0 & 30.2 & 38.2 & 19.4 & 5.7 & 0.5 & $\mathrm{CS}$ \\
\hline & $15-35$ & 0.20 & 17.7 & 0.0 & 1.1 & 30.5 & 43.7 & 17.6 & 6.6 & 0.5 & $\mathrm{CS}$ \\
\hline & $35-90$ & 0.24 & 18.0 & 0.0 & 0.0 & 7.0 & 50.5 & 35.6 & 6.6 & 0.3 & MS \\
\hline & $90-150$ & 0.33 & 17.7 & 0.0 & 0.4 & 12.6 & 52.9 & 26.8 & 6.8 & 0.5 & MS \\
\hline \multirow[t]{4}{*}{8} & $0-20$ & 0.23 & 18.0 & 0.0 & 1.3 & 27.6 & 43.9 & 20.0 & 6.6 & 0.6 & $\mathrm{CS}$ \\
\hline & $20-70$ & 0.20 & 19.0 & 0.0 & 0.0 & 8.4 & 54.6 & 30.6 & 6.0 & 0.4 & MS \\
\hline & $70-100$ & 0.22 & 18.7 & 0.0 & 0.0 & 11.6 & 57.4 & 24.0 & 6.7 & 0.3 & MS \\
\hline & $100-150$ & 0.26 & 18.0 & 0.0 & 0.3 & 26.8 & 44.8 & 17.8 & 9.3 & 1.0 & CS \\
\hline
\end{tabular}


Table 3. Some chemical analyses in experimental soils

\begin{tabular}{|c|c|c|c|c|c|c|c|c|c|c|c|c|}
\hline \multirow{2}{*}{$\begin{array}{c}\text { Parcel } \\
\text { No. }\end{array}$} & \multirow{2}{*}{$\begin{array}{l}\text { Depth } \\
\text { (cm) }\end{array}$} & \multirow[t]{2}{*}{ pH } & \multirow{2}{*}{$\begin{array}{c}\text { EC } \\
\text { ds } / m\end{array}$} & \multicolumn{4}{|c|}{ Soluble cations (m.eq/L) } & \multicolumn{3}{|c|}{ Soluble anions (m.eq/L) } & \multirow[t]{2}{*}{ SAR } & \multirow[t]{2}{*}{ ESP } \\
\hline & & & & $\mathrm{Na}^{+}$ & $\mathbf{K}^{+}$ & $\mathrm{Ca}^{++}$ & $\mathbf{M g}^{++}$ & $\mathrm{HCO}_{3}^{-}$ & $\mathrm{CI}^{+}$ & $\mathrm{SO}_{4}^{-}$ & & \\
\hline \multirow[t]{4}{*}{6} & $0-15$ & 7.95 & 0.72 & 3.85 & 0.36 & 1.66 & 1.33 & 1.99 & 3.32 & 1.89 & 3.15 & 3.27 \\
\hline & $15-35$ & 8.34 & 0.55 & 2.72 & 0.29 & 1.43 & 1.07 & 1.72 & 2.86 & 0.93 & 2.43 & 2.26 \\
\hline & $35-90$ & 8.10 & 0.69 & 3.49 & 0.37 & 1.74 & 1.31 & 2.18 & 3.49 & 1.31 & 2.82 & 2.81 \\
\hline & $90-150$ & 8.19 & 0.56 & 2.67 & 0.44 & 1.42 & 1.07 & 1.78 & 2.85 & 0.98 & 2.39 & 2.21 \\
\hline \multirow[t]{4}{*}{8} & $0-20$ & 8.32 & 0.71 & 5.68 & 0.06 & 0.82 & 0.54 & 1.63 & 4.90 & 0.56 & 6.89 & 8.15 \\
\hline & $20-70$ & 8.29 & 0.63 & 4.78 & 0.06 & 0.82 & 0.64 & 1.37 & 2.93 & 2.00 & 5.59 & 6.51 \\
\hline & $70-100$ & 8.62 & 0.31 & 2.23 & 0.03 & 0.53 & 0.33 & 0.33 & 2.34 & 0.42 & 5.09 & 6.50 \\
\hline & $100-150$ & 8.17 & 1.41 & 10.39 & 0.13 & 2.12 & 1.46 & 2.28 & 9.76 & 2.00 & 7.76 & 9.23 \\
\hline
\end{tabular}

SAR, and ESP are sodium adsorption ratio and exchange sodium percent, respectively.

Table 4. Available nutrients status and OM (\%) in the experimental soils

\begin{tabular}{|c|c|c|c|c|c|c|c|c|c|}
\hline \multirow{2}{*}{$\begin{array}{c}\text { Parcel } \\
\text { No. }\end{array}$} & \multirow{2}{*}{$\begin{array}{c}\text { Depth } \\
\text { (cm) }\end{array}$} & \multicolumn{7}{|c|}{ Available nutrients (ppm) } & \multirow{2}{*}{$\begin{array}{l}\text { OM } \\
(\%)\end{array}$} \\
\hline & & $\mathbf{N}$ & $\mathbf{P}$ & $\bar{K}$ & $\mathbf{F e}$ & Mn & $\mathbf{Z n}$ & $\mathbf{C u}$ & \\
\hline \multirow[t]{4}{*}{6} & $0-15$ & 45.8 & 1.34 & 13.9 & 5.30 & 4.32 & 0.134 & 0.170 & 0.328 \\
\hline & $15-35$ & 48.2 & 2.48 & 16.6 & 4.93 & 1.82 & 0.122 & 0.130 & 0.188 \\
\hline & $35-90$ & 34.0 & 3.20 & 26.6 & 4.32 & 1.41 & 0.410 & 0.138 & 0.061 \\
\hline & $90-150$ & 21.6 & 2.87 & 23.6 & 2.88 & 1.40 & 0.882 & 0.136 & 0.053 \\
\hline \multirow[t]{4}{*}{8} & 0-20 & 54.0 & 2.25 & 41.0 & 5.84 & 1.71 & 0.128 & 0.494 & 0.331 \\
\hline & 20-70 & 44.4 & 3.23 & 41.0 & 4.83 & 1.10 & 0.120 & 0.204 & 0.256 \\
\hline & $70-100$ & 34.8 & 2.71 & 34.4 & 6.91 & 1.80 & 0.374 & 0.180 & 0.194 \\
\hline & $100-150$ & 39.2 & 2.55 & 22.2 & 6.32 & 1.41 & 0.404 & 0.228 & 0.112 \\
\hline
\end{tabular}

Table 5. Chemical analysis of water used in irrigation and heavy and nutrient content in water used in irrigation

\begin{tabular}{|c|c|c|c|c|c|c|c|c|c|c|c|c|c|c|}
\hline $\begin{array}{l}\text { Water } \\
\text { source }\end{array}$ & pH & $\begin{array}{c}\mathbf{E C} \\
(\mu \mathrm{S} / \mathrm{cm})\end{array}$ & $\begin{array}{c}\text { TDS } \\
(\mathrm{mg} / \mathrm{I})\end{array}$ & Units & $\mathrm{Ca}^{++}$ & $\overline{\mathbf{M g}^{++}}$ & $\mathrm{Na}^{+}$ & $\overline{\mathbf{K}^{+}}$ & $\begin{array}{c}\text { Total } \\
\text { cations } \\
(\mathrm{epm})\end{array}$ & $\mathrm{CO}_{3}^{--}$ & $\mathrm{HC}$ & - & $\mathrm{Cr}$ & $\begin{array}{c}\text { Total } \\
\text { anions } \\
(\text { epm) }\end{array}$ \\
\hline \multirow[t]{3}{*}{ Canal } & 8.3 & 2960 & 1609.7 & $\mathrm{ppm}$ & 134.5 & 101.9 & 330 & 11 & 29.73 & $\overline{9}$ & 176.9 & 148.8 & 786 & 28.47 \\
\hline & & & & epm & 6.71 & 8.39 & 14.35 & 0.28 & & 0.3 & 2.9 & 3.1 & 22.17 & \\
\hline & & & & $(\%)$ & 22.56 & 28.22 & 48.26 & 0.94 & & 1.05 & 10.19 & 10.89 & 1267.7 & \\
\hline \multirow[t]{3}{*}{ Well } & 7.9 & 4990 & 2952.3 & ppm & 123.4 & 105.8 & 840 & 7 & & 6 & 149.5 & 527.7 & 35.75 & \\
\hline & & & & epm & 6.16 & 8.82 & 36.52 & 0.18 & 51.68 & 0.2 & 2.45 & 10.98 & 35.75 & 49.38 \\
\hline & & & & (\%) & 11.92 & 17.06 & 70.67 & 0.35 & & 0.41 & 4.96 & 22.24 & 72.39 & \\
\hline
\end{tabular}

Table 5. Continued

\begin{tabular}{lcccccccccccccc}
\hline $\begin{array}{l}\text { Water } \\
\text { source }\end{array}$ & Al & B & Fe & Mn & Pb & Cd & Co & Cr & Cu & Mo & Ni & Sr & V & Zn \\
\hline Canal & 0.143 & 0.179 & 0.189 & 0.011 & 0.009 & $<0.001$ & $<0.001$ & $<0.02$ & 0.025 & $<0.003$ & 0.002 & 2.56 & $<0.01$ & 0.029 \\
Well & $<0.06$ & 1.21 & $<0.03$ & $<0.002$ & 0.027 & $<0.001$ & $<0.001$ & 0.053 & $<0.01$ & $<0.003$ & 0.002 & 2.46 & $<0.01$ & 0.578 \\
\hline
\end{tabular}


Table 6. Relative humidity and minimum and maximum temperatures in El-Qantara Shark during the 2013/214 and 2014/2015 winter barley growing seasons

\begin{tabular}{llccccccc}
\hline Year & Variable & \multicolumn{7}{c}{ Month } \\
\cline { 3 - 9 } & & October & November & December & January & February March & April \\
\hline \multirow{2}{*}{$\mathbf{2 0 1 3 / 2 0 1 4}$} & Relative humidity & 65.9 & 66.9 & 68.1 & 65.1 & 61.2 & 62.4 & 64.9 \\
& Average daily minimum & 16.4 & 12.9 & 9.0 & 8.0 & 8.5 & 9.9 & 12.4 \\
& Average daily maximum & 28.5 & 24.2 & 19.9 & 18.3 & 18.7 & 20 & 22 \\
& Relative humidity & 63.3 & 64.2 & 65.9 & 63.3 & 59.6 & 60.8 & 61.5 \\
$\mathbf{2 0 1 4 / 2 0 1 5}$ & Average daily minimum & 17.4 & 13 & 9.5 & 8.8 & 8.9 & 10.5 & 13.0 \\
& Average daily maximum & 28.8 & 25.0 & 20.5 & 19.4 & 19.2 & 21.0 & 23.0 \\
\hline
\end{tabular}

The three water treatments received an equal number of irrigations. The water used in irrigation was mixed from El-Salam Canal and water wells. Rainfall, minimum and maximum temperatures were recorded from meteorological stations (Table 6).

\section{Studied Traits}

Days to heading (DH), was measured as number of days from sowing to awns appearance in $50 \%$ of the plants in a plot. Plant height $(\mathrm{PH})$, in $\mathrm{cm}$ was estimated from ground level to the top of the spike excluding awns, at maturity. Flag leaf area (FLA), in $\mathrm{cm}^{2}$ was calculated according to the following formula, Flag leaf area $=$ length $\times$ maximum width $\times 0.72$ (Lai and Subba Roa, 1951). 1000 grain weight (GW), was determined from two random samples taken from each plot and the average was calculated (g). Biological yield (BY) and grain yield (GY) were estimated from the central rows in the plot after discarding the first and the last row to avoid border effect and the biological yield (ton/fad.) and the yield of grains (ardab/fad.) were calculated.

\section{Statistical Analyses}

The combined analyses of variance were performed according to Steel et al. (1997). The phenotypic stability analysis was computed as outlined by Eberhart and Russell (1966). The genotypic stability analysis was calculated according to Tai (1971). The additive main effects and multiplicative interaction method (AMMI) was computed as proposed by Gauch (1992). Differences among means were tested using a revised LSD test at the 0.05 level according to Steel et al. (1997). A PC Microsoft
Excel program and SAS 9.1 ® Computer program for Windows were used for the statistical analyses.

\section{RESULTS AND DISCUSSION}

\section{Analysis of Variance}

The combined analyses of variance for days to $50 \%$ heading, plant height, flag leaf area, 1000-grain weight, biological yield (ton/fad.) and grain yield (ardab/fad.) (Table 7) showed highly significant differences among environments for all traits, suggesting that the environments under study were different. Furthermore, highly significant effects among years $(\mathrm{Y})$ were obtained for the forgoing traits. This result reflects the wide differences in climatic conditions prevailing during the growing seasons. Moreover, the main effect of irrigation (I) was highly significant for all studied traits. Likewise, the studied barley genotypes $(G)$ had also highly significant differences for all characters, reflecting the wide genetic diversity.

Subsequently, significant $\mathrm{G} \times \mathrm{E}$ items were detected for all studied traits, provide evidence that the studied barley genotypes differed in their response to the environmental conditions, suggestting that is essential to determine the degree of stability for each genotype.

The first order interaction of years $x$ irrigation levels $(\mathrm{Y} \times \mathrm{I})$ significantly differed for all traits except days to $50 \%$ heading, indicating the different influences of climatic conditions on irrigation treatments. Also, highly significant interactions between genotypes $\times$ years $(\mathrm{G} \times \mathrm{Y})$ were found for flag leaf area and biological yield. Moreover, the combined analyses of variance showed highly significant interactions 
Table 7. The combined analyses of variance over two years, water stress levels and genotypes for studied traits

\begin{tabular}{|c|c|c|c|c|c|c|c|}
\hline SOV & df & $\begin{array}{c}\text { Days to } 50 \% \\
\text { heading }\end{array}$ & $\begin{array}{l}\text { Plant height } \\
\text { (cm) }\end{array}$ & $\begin{array}{l}\text { Flag leaf } \\
\text { area }\left(\mathrm{cm}^{2}\right)\end{array}$ & $\begin{array}{l}1000 \text { grain } \\
\text { weight }(g)\end{array}$ & $\begin{array}{c}\text { Biological } \\
\text { yield } \\
\text { (ton/fad.) }\end{array}$ & $\begin{array}{l}\text { Grain yield } \\
\text { (ardab/fad.) }\end{array}$ \\
\hline 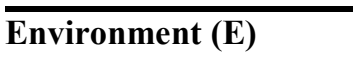 & 5 & $1317.90^{* *}$ & $5252.17^{* 2}$ & $96.62^{* *}$ & $152.83^{* *}$ & $35.09^{* *}$ & $167.40^{* *}$ \\
\hline Reps/Env. (Error a) & 12 & 2.36 & 17.92 & 4.01 & 5.49 & 0.24 & 1.58 \\
\hline Years (Y) & 1 & $676.00^{* *}$ & $6198.94^{* *}$ & $243.0^{* *}$ & $95.29^{* *}$ & 0.00 & $43.03^{* *}$ \\
\hline $\mathbf{Y} \times \mathbf{I}$ & 2 & 4.15 & $62.15^{* *}$ & $18.67^{* *}$ & $24.97^{* *}$ & $1.07^{* *}$ & $1.38^{* *}$ \\
\hline Irrigation (I) & 2 & $2952.60^{* *}$ & $9968.81^{* *}$ & $101.38^{* *}$ & $309.45^{* *}$ & $86.66^{* *}$ & $395.60^{* *}$ \\
\hline Genotypes (G) & 17 & $528.64^{* *}$ & $174.16^{* *}$ & $40.45^{* *}$ & $26.74^{* *}$ & $2.98^{* *}$ & $37.06^{* *}$ \\
\hline $\mathbf{G} \times \mathbf{E}$ & 85 & $9.82^{* *}$ & $10.31^{*}$ & $6.84^{* *}$ & $3.03^{*}$ & $0.18^{*}$ & $0.65^{*}$ \\
\hline $\mathbf{G} \times \mathbf{Y}$ & 17 & 1.91 & 4.55 & $5.56^{* *}$ & 0.10 & $0.35^{* *}$ & 0.67 \\
\hline $\mathbf{G} \times \mathbf{I}$ & 34 & $21.08^{* *}$ & $20.87^{* *}$ & $4.96^{* *}$ & $7.42^{* *}$ & 0.17 & $0.92^{* *}$ \\
\hline $\mathbf{G} \times \mathbf{Y} \times \mathbf{I}$ & 34 & 2.53 & 2.64 & $9.35^{* *}$ & 0.09 & 0.11 & 0.37 \\
\hline Pooled Error (Error b) & 204 & 2.51 & 7.14 & 0.41 & 2.23 & 0.12 & 0.42 \\
\hline CV (\%) & & 1.80 & 4.83 & 7.44 & 3.87 & 7.93 & 5.12 \\
\hline
\end{tabular}

*, ** Significant at 0.05 and 0.01 levels of probability, respectively.

between genotypes and irrigation levels $(\mathrm{G} \times \mathrm{I})$ for all characters except biological yield. For this reason, the genotype-irrigation interaction component $(\mathrm{G} \times \mathrm{I})$ accounted for the most part of total $\mathrm{G} \times \mathrm{E}$ interaction, indicating that irrigation treatments had the major effect on the relative genotypic potential for these studied traits. Conversely, for the second $\operatorname{order}(\mathrm{G} \times \mathrm{Y} \times$ I) interactions, there weren't a differential response between genotypes to years and irrigation levels for all traits except flag leaf area. These results are in harmony with those obtained by Chand et al. (2008), Lodhi et al. (2015), Feriani et al. (2016) and Ramla et al. (2016).

\section{Mean Relatively Performance}

The analyses of variance revealed significant differences for all studied traits among the eighteen barley genotypes in both $1^{\text {st }}$ and $2^{\text {nd }}$ seasons of the three irrigation levels. Severe and moderate water stress levels caused significant reduction in all studied traits except 1000-grain weight for all barley genotypes than adequate water supply treatment (data not shown). It is clear that, the irrigation stresses caused a reduction in days to $50 \%$ heading in the $1^{\text {st }}$ year by an average of $11.3 \%$ and $2.9 \%$ and in the $2^{\text {nd }}$ year by an average of $10.7 \%$ and $3.5 \%$ under $1^{\text {st }}$ and $2^{\text {nd }}$ irrigation levels, respectively, compared with the $3^{\text {rd }}$ level (adequate). For plant height, the reduction percentages were $30.21 \%$ and $10.38 \%$ in the $1^{\text {st }}$ year as well as $29.32 \%$ and $12.70 \%$ in the $2^{\text {nd }}$ year under $1^{\text {st }}$ and $2^{\text {nd }}$ irrigation levels, respectively, compared with the $3^{\text {rd }}$ level (adequate).

Reduction percentages for flag leaf area were $27.96 \%$ and $19.84 \%$ in the $1^{\text {st }}$ year as well as $12.72 \%$ and $2.95 \%$ in the $2^{\text {nd }}$ year under $1^{\text {st }}$ and $2^{\text {nd }}$ irrigation levels, respectively, compared with the $3^{\text {rd }}$ level. Also, reduction percentages for biological yield were $30.87 \%$ and $12.99 \%$ in the $1^{\text {st }}$ year as well as $37.23 \%$ and $15.70 \%$ in the $2^{\text {one }}$ one under $1^{\text {st }}$ and $2^{\text {nd }}$ irrigation levels, respectively, compared with the $3^{\text {rd }}$ level.

Correspondingly, grain yield reduced in the $1^{\text {st }}$ year by an average of $25.67 \%$ and $13.44 \%$ as well as in the $2^{\text {nd }}$ year by an average of $26.82 \%$ and $12.67 \%$ under $1^{\text {st }}$ and $2^{\text {nd }}$ irrigation levels, respectively, compared with the $3^{\text {rd }}$ level. 
Generally, grain yield and other traits were severely decreased at the first and second irrigation levels when compared with the third level. Similar trend of results were reported by Sánchez-Díaz et al. (2002), Samarah et al. (2009), Sharafi et al. (2011), Haddadin (2015) and Al-Ajlouni et al. (2016). Moreover, Samarah (2005) found that the drought-stressed plants had shorter duration of grain filling than well-watered plants and reduced grain yield by reducing the number of tillers, spikes and grains per plant and individual grain weight.

The average of days to $50 \%$ heading over all environments varied from 79.0 (Giza 123) to 99.17 day (Line 1) with an average 87.13 day. In continuous, and as shown in Table 10. It is worthy to note that, plant height varied from 48.19 (Line 3) to $61.24 \mathrm{~cm}$ (Line 7) with an average of $55.12 \mathrm{~cm}$. For flag leaf area, it ranged from 6.29 (Line 5) to $13.18 \mathrm{~cm}^{2}$ (Giza 2000) with an average of $8.10 \mathrm{~cm}^{2}$ across 6 environments (Table 11). Whereas, 1000- grain weight ranged from 36.91 (Line 10) to $40.82 \mathrm{~g}$ (Line 1) with an average of 38.43g. Moreover, biological yield varied from 3.73 (Giza 2000) to 5.0 (Line 6) with an average of 4.51 (ton/fad.) over six environments. In the same way, grain yield varied from 10.69 (Giza 126) to 15.07 (Line 6) with an average of 13.17 (ardab/fad.). (Table 12). These results are in well agreement with those of Sharafi et al. (2011), Haddadin (2015) and Al-Ajlouni et al. (2016). Moreover, Ceccarelli et al. (1987) reported that environmental stresses such as drought, salinity, heat and cold are common, and together with low soil fertility and traditional agronomic managements are the major cause of low barley productivity (about 1.0 ton/ha).

\section{Regression Analysis}

Mean squares due to joint regression analysis of variance for days to $50 \%$ heading, plant height, flag leaf area, 1000-grain weight, biological yield and grain yield of the eighteen barley genotypes under six environments are presented in (Table 8). Results revealed significant differences among genotypes $(\mathrm{G})$, environments (E) and the $G \times E$ interaction for all traits, indicating the presence of genetic and environmental variability among the studied genotypes. Environment + Genotype $\times$
Environment $(E+G \times E)$ had highly significant effects for all characters. The $\mathrm{G} \times \mathrm{E}$ interaction was further partitioned into linear and non-linear (pooled deviation) components. The mean squares due to environment (linear) were highly significant for all traits, indicating that differences existed between environments and revealed predictable component shared $\mathrm{G} \times \mathrm{E}$ interaction with un-predictable. Additionally, the linear interaction $(\mathrm{G} \times \mathrm{E}$ linear) was highly significant when tested against pooled deviation for all these characters, showing genetic differences among genotypes for their regression on the environmental-index, so it could be proceeded in the stability analysis (Eberhart and Russell, 1966) for the studied characters.

The non-linear responses as measured by pooled deviations from regressions were highly significant for days to $50 \%$ heading and flag leaf area, indicating that differences in linear response among genotypes across environments did account for all the $G \times E$ interaction effects, and therefore, the fluctuation in performance of genotypes grown in various environments was fully predictable. Significant effects for G x E interaction for many barley characters were previously reported (Chand et al., 2008; Lodhi et al., 2015; Feriani et al., 2016; Ramla et al., 2016).

\section{Days to 50\% Heading}

Phenotypic stability parameters have been computed according to Eberhart and Russell (1966), for evaluating the eighteen barley genotypes for mentioned traits.

The importance of both linear $\left(b_{i}\right)$ and nonlinear $\left(\mathrm{s}_{\mathrm{di}}^{2}\right)$ sensitivity for the expression of the trait was thus evident. Eberhart and Russell (1966) procedure involves the use of joint linear regression where the yield of each genotype is regressed on the environmental mean yield.

Results obtained in Table 10 clarify that, the regression coefficient $\left(b_{i}\right)$ of barley genotypes ranged from 0.62 (Line 4) to 1.36 (Line 13) for days to $50 \%$ heading, indicating the genetic variability among barley genotypes in their regression response. However, the obtained $\left(b_{i}\right)$ values were not deviated significantly from unity in barley genotypes; Line 1, Line 6, Line 8, Line 9, Line 10, Line 11, Rihane 3, Giza 2000 
Table 8. Joint regression analysis of variance over two years, water irrigation levels and genotypes for studied traits

\begin{tabular}{|c|c|c|c|c|c|c|c|}
\hline Traits & df & $\begin{array}{c}\text { Days to } \\
50 \% \\
\text { heading }\end{array}$ & $\begin{array}{c}\text { Plant } \\
\text { height } \\
(\mathrm{cm})\end{array}$ & $\begin{array}{c}\text { Flag leaf } \\
\text { area } \\
\left(\mathrm{cm}^{2}\right)\end{array}$ & $\begin{array}{l}1000 \text { grain } \\
\text { weight } \\
\text { (g) }\end{array}$ & $\begin{array}{c}\text { Biological } \\
\text { yield } \\
\text { (ton/fad.) }\end{array}$ & $\begin{array}{c}\text { Grain } \\
\text { yield } \\
\text { (ardab/fad.) }\end{array}$ \\
\hline Model & 107 & $51.13^{* *}$ & $93.76^{* *}$ & $5.46^{* *}$ & $4.60^{* *}$ & $0.75^{* *}$ & $4.74^{* *}$ \\
\hline Genotype (G) & 17 & $176.21^{* *}$ & $58.05^{* *}$ & $13.48^{* *}$ & $8.91^{* *}$ & $0.99^{* *}$ & $12.35^{* *}$ \\
\hline Environment (E) & 5 & $439.30^{* *}$ & $1750.72^{* *}$ & $32.21^{* *}$ & $50.94^{* *}$ & $11.70^{* *}$ & $55.80^{* *}$ \\
\hline $\mathbf{G} \times \mathbf{E}$ & 85 & $3.27^{* *}$ & $3.44^{*}$ & $2.28^{* *}$ & $1.01^{*}$ & $0.06^{*}$ & $0.22^{*}$ \\
\hline $\mathbf{E}+\mathbf{G} \times \mathbf{E}$ & 90 & $27.50^{* *}$ & $100.51^{* *}$ & $3.94^{* *}$ & $3.78^{* *}$ & $0.71^{* *}$ & $3.30^{* *}$ \\
\hline Environment (linear) & 1 & $1220.28^{* *}$ & $4863.12^{* *}$ & $89.46^{* *}$ & $141.51^{* *}$ & $32.49^{* *}$ & $155.00^{* *}$ \\
\hline $\mathbf{G} \times \mathbf{E}$ (linear) & 17 & $68.40^{* *}$ & $234.45^{* *}$ & $6.80^{* *}$ & $9.51^{* *}$ & $1.60^{* *}$ & $7.71^{* *}$ \\
\hline Pooled deviation & 72 & $1.27^{* *}$ & 2.74 & $2.08^{* *}$ & 0.52 & 0.05 & 0.16 \\
\hline Pooled Error & 204 & 0.84 & 2.38 & 0.14 & 0.74 & 0.04 & 0.14 \\
\hline
\end{tabular}

*,** Significant at 0.05 and 0.01 levels of probability, respectively.

Table 9. AMMI analysis of variance over six environments (two years and three water irrigation levels) for studied traits

\begin{tabular}{|c|c|c|c|c|c|c|c|c|c|c|c|c|c|}
\hline \multirow[b]{2}{*}{ SOV } & \multirow[t]{2}{*}{ df } & \multicolumn{2}{|c|}{$\begin{array}{l}\text { Days to } 50 \% \\
\text { heading }\end{array}$} & \multicolumn{2}{|c|}{$\begin{array}{l}\text { Plant height } \\
\text { (cm) }\end{array}$} & \multicolumn{2}{|c|}{$\begin{array}{c}\text { Flag leaf area } \\
\left(\mathrm{cm}^{2}\right)\end{array}$} & \multicolumn{2}{|c|}{$\begin{array}{l}1000 \text { grain } \\
\text { weight (g) }\end{array}$} & \multicolumn{2}{|c|}{$\begin{array}{l}\text { Biological yield } \\
\text { (ton/fad.) }\end{array}$} & \multicolumn{2}{|c|}{$\begin{array}{l}\text { Grain yield } \\
\text { (ardab/fad.) }\end{array}$} \\
\hline & & MS & Percent & MS & Percent & MS & Percent & MS & Percent & MS & Percent & MS & Percent \\
\hline Environment (E) & 5 & $1317.90^{* *}$ & 38.87 & $5252.17^{* *}$ & 80.59 & $96.62^{* *}$ & 25.65 & $152.83^{\text {** }}$ & 33.18 & $35.09^{* *}$ & 65.21 & $167.40^{* *}$ & 48.56 \\
\hline Reps/Env. & 12 & 2.36 & & 17.92 & & 4.01 & & 5.49 & & 0.24 & & 1.58 & \\
\hline Genotype (G) & 17 & $528.64^{* *}$ & 53.01 & $174.16^{* *}$ & 9.09 & $40.45^{* *}$ & 36.51 & $26.74^{* *}$ & 19.74 & $2.98^{* *}$ & 18.84 & $37.06^{* *}$ & 36.55 \\
\hline $\mathbf{G} \times \mathbf{E}$ & 85 & $9.82^{* *}$ & 4.93 & $10.31^{*}$ & 2.69 & $6.84^{* *}$ & 30.84 & $3.03^{*}$ & 11.17 & $0.18^{*}$ & 5.69 & $0.65^{*}$ & 3.20 \\
\hline IPCA1 & 21 & $32.27^{* *}$ & 81.16 & $20.97^{* *}$ & 50.23 & $11.66^{* *}$ & 42.14 & $8.55^{* *}$ & 69.79 & $0.36^{* *}$ & 49.83 & $1.15^{* *}$ & 43.91 \\
\hline IPCA2 & 19 & $6.76^{* *}$ & 15.38 & $16.52^{* *}$ & 35.79 & $8.85^{* *}$ & 28.93 & $3.85^{* *}$ & 28.48 & $0.19^{*}$ & 23.82 & $1.10^{* *}$ & 37.84 \\
\hline IPCA3 & 17 & 0.81 & 1.64 & 4.34 & 8.41 & $7.66^{* *}$ & 22.40 & 0.19 & 1.26 & 0.12 & 12.83 & 0.51 & 15.85 \\
\hline IPCA4 & 15 & 0.73 & 1.31 & 2.14 & 3.66 & $2.32^{* *}$ & 6.00 & 0.06 & 0.32 & 0.10 & 10.09 & 0.07 & 1.95 \\
\hline IPCA5 & 13 & 0.33 & 0.51 & 1.29 & 1.91 & 0.24 & 0.53 & 0.03 & 0.16 & 0.04 & 3.42 & 0.02 & 0.45 \\
\hline Pooled Error & 204 & 2.51 & & 7.14 & & 0.41 & & 2.23 & & 0.12 & & 0.42 & \\
\hline
\end{tabular}

*, ** Significant at 0.05 and 0.01 levels of probability, respectively. 
Table 10. Genotype means over six environments and stability parameters of the eighteen barley genotypes for days to $50 \%$ heading and plant height

\begin{tabular}{|c|c|c|c|c|c|c|c|c|c|c|c|c|c|c|c|c|}
\hline \multirow[b]{2}{*}{ Genotype } & \multicolumn{8}{|c|}{ Days to $50 \%$ heading } & \multicolumn{8}{|c|}{ Plant height (cm) } \\
\hline & $\begin{array}{c}\text { Mean } \\
\left(\bar{g}_{i}\right)\end{array}$ & $\overline{\mathbf{P}_{\mathrm{i}}}$ & $\overline{b_{i}}$ & $\mathrm{~S}_{\mathrm{di}}^{2}$ & $\overline{\alpha_{i}}$ & $\overline{\lambda_{i}}$ & $\overline{A S V}$ & Rank & $\begin{array}{c}\text { Mean } \\
\left(\overline{\bar{g}}_{i}\right)\end{array}$ & $\overline{\mathbf{P}_{\mathrm{i}}}$ & $\overline{b_{i}}$ & $\mathrm{~S}_{\mathrm{di}}^{2}$ & $\overline{\alpha_{i}}$ & $\lambda_{\mathrm{i}}$ & $\overline{\mathrm{ASV}}$ & Rank \\
\hline $\begin{array}{l}\text { (California } \\
\text { riout) }\end{array}$ & 81.44 & -5.69 & $0.75^{* *}$ & 0.28 & $-0.25^{*}$ & $0.28^{*}$ & 3.52 & 13 & 52.13 & -2.99 & 1.05 & 3.87 & 0.05 & 0.88 & 2.73 & 8 \\
\hline G2 (Line 1) & 99.17 & 12.03 & 1.15 & 0.80 & 0.15 & 0.81 & 2.42 & 11 & 54.77 & -0.35 & 1.22 & $7.23^{*}$ & 0.22 & 1.65 & 9.89 & 18 \\
\hline G3 (Line 2) & 87.22 & 0.09 & $1.85^{* *}$ & $2.50^{*}$ & $0.85^{*}$ & 2.49 & 13.09 & 18 & 52.62 & -2.50 & 1.01 & 3.89 & 0.01 & 0.89 & 1.88 & 5 \\
\hline G4 (Line 3) & 79.17 & -7.97 & $0.89^{* *}$ & 0.16 & $-0.11^{*}$ & $0.16^{*}$ & 1.84 & 7 & 48.19 & -6.93 & 1.00 & 4.18 & 0.00 & 0.95 & 2.72 & 7 \\
\hline G5 (Giza 123) & 79.00 & -8.13 & $0.85^{* *}$ & 0.11 & $-0.15^{*}$ & $0.11^{*}$ & 2.23 & 10 & 52.50 & -2.62 & $1.13^{* *}$ & 0.19 & $0.13^{*}$ & $0.04^{*}$ & 3.87 & 13 \\
\hline G6 (Line 4) & 91.22 & 4.09 & $0.62^{* *}$ & 1.33 & $-0.38^{*}$ & 1.33 & 6.47 & 16 & 55.12 & 0.00 & 0.86 & 3.60 & -0.15 & 0.82 & 5.71 & 15 \\
\hline G7 (Line 5) & 92.72 & 5.59 & $0.69^{* *}$ & 0.15 & $-0.31^{*}$ & $0.14^{*}$ & 4.44 & 14 & 56.53 & 1.41 & 1.05 & 0.80 & 0.05 & $0.18^{*}$ & 1.05 & 2 \\
\hline G8 (Line 6) & 90.78 & 3.64 & 1.00 & 0.17 & 0.004 & $0.17^{*}$ & 0.48 & 2 & 52.86 & -2.27 & 0.97 & 0.93 & -0.03 & $0.21^{*}$ & 0.36 & 1 \\
\hline G9 (Line 7) & 86.39 & -0.75 & $1.19^{* *}$ & 0.39 & $0.19^{*}$ & 0.40 & 2.96 & 12 & 61.24 & 6.12 & 1.01 & 1.65 & 0.01 & $0.38^{*}$ & 1.78 & 4 \\
\hline G10 (Line 8) & 84.83 & -2.30 & 1.10 & 0.54 & 0.10 & 0.55 & 2.16 & 9 & 57.62 & 2.50 & 1.09 & $7.44^{* *}$ & 0.09 & 1.70 & 5.40 & 14 \\
\hline G11 (Line 9) & 83.89 & -3.25 & 0.97 & 0.12 & -0.03 & $0.13^{*}$ & 0.30 & 1 & 59.21 & 4.09 & 0.86 & 2.09 & -0.14 & 0.47 & 5.91 & 16 \\
\hline G12 (Line 10) & 89.78 & 2.64 & 0.98 & 0.37 & -0.02 & 0.37 & 0.81 & 5 & 58.65 & 3.53 & 1.01 & 3.46 & 0.01 & 0.79 & 1.14 & 3 \\
\hline G13 (Line 11) & 87.28 & 0.14 & 1.01 & 0.72 & 0.01 & 0.73 & 1.05 & 6 & 55.46 & 0.34 & $0.79^{*}$ & 2.62 & $-0.21^{*}$ & 0.59 & 8.31 & 17 \\
\hline G14 (Line 12) & 90.33 & 3.20 & $0.50^{* *}$ & $12.75^{* *}$ & $-0.50^{*}$ & $12.89^{*}$ & 10.60 & 17 & 58.48 & 3.36 & 0.96 & 2.01 & -0.05 & 0.46 & 3.00 & 11 \\
\hline G15 (Line 13) & 83.56 & -3.58 & $1.36^{* *}$ & 0.65 & $0.36^{*}$ & 0.65 & 5.71 & 15 & 55.61 & 0.49 & 0.89 & 2.16 & -0.11 & 0.49 & 2.86 & 9 \\
\hline (Rihane 3) & 89.61 & 2.48 & 1.05 & 0.06 & $0.05^{*}$ & $0.06^{*}$ & 0.74 & 3 & 53.39 & -1.73 & $1.12^{* *}$ & 0.50 & $0.12^{*}$ & $0.11^{*}$ & 2.72 & 7 \\
\hline G17 (Giza 2000) & 94.44 & 7.31 & 1.09 & 0.42 & 0.09 & 0.53 & 1.98 & 8 & 55.53 & 0.41 & 1.04 & 0.84 & 0.04 & $0.24^{*}$ & 2.91 & 10 \\
\hline G18 (Giza 126) & 93.39 & 6.25 & 0.95 & 0.88 & -0.05 & 1.34 & 0.76 & 4 & 55.44 & 0.32 & 0.95 & 1.07 & -0.05 & $0.37^{*}$ & 3.46 & 12 \\
\hline & 87.13 & & & & & & & & 55.12 & & & & & & & \\
\hline LSD' 0.05 & 0.96 & & & & & & & & 1.73 & & & & & & & \\
\hline
\end{tabular}

$\overline{\mathrm{g}_{\mathrm{i}}}=$ Mean of genotype, $\left(\mathrm{P}_{\mathrm{i}}\right)=$ Phenotypic index $\left(\overline{\mathrm{g}_{\mathrm{i}}} \overline{\overline{\mathrm{X}}}\right), \mathrm{b}_{\mathrm{i}}=$ regression coefficient and $\mathrm{S}_{\mathrm{di}}^{2}=$ mean square deviations from linear regression, $\alpha_{\mathrm{i}}=$ linear response to environmental effects, $\lambda_{\mathrm{i}}=$ the deviation from linear response and ASV $=$ AMMI stability value.

*, ** Significant at 0.05 and 0.01 levels of probability, respectively.

and Giza 126 for this trait, indicating that these genotypes could be grown under wide range of environments.

Four barley genotypes i.e., Line 6, Line 11, Rihane 3 and Giza 2000 exhibited regression coefficient $\left(b_{i}\right)$ values equal unity, therefore could be grown under wide range of environments. Meanwhile, the barley genotypes Line 9, Line 10 and Giza 126 had $b_{i}<1$ and not significant. In contrast, the barley genotypes, Line 1 , and Line 8 had $b_{i}>1$ and not significant. According to Breese (1969) genotypes with regression coefficient greater than unity would be adapted to more favorable environments.
While, those with coefficient less than one would relatively be better adapted to less favorable growing conditions.

The deviations from regression $\left(\mathrm{s}_{\mathrm{di}}^{2}\right)$ ranged from 0.06 (Rihane 3) to 12.75 (Line 12). All studied barely genotypes were stable, because they had lowest $\mathrm{s}_{\mathrm{di}}^{2}$ values and not significant except Line 2, Line 4 and Line 12.

When the mean performance $(\bar{g})$, regression coefficient value $\left(b_{i}\right)$ and the deviation from the regression $\left(\mathrm{s}_{\mathrm{di}}^{2}\right)$ are considered together, then the most stable genotype would be Line 9 with an earliest mean $\bar{g}=83.89, \mathrm{~b}_{\mathrm{i}}=0.97$ and $\mathrm{s}_{\mathrm{di}}^{2}=$ 
0.12; Rihane 3 with $\bar{g}=89.61, \mathrm{~b}_{\mathrm{i}}=1.05$ and $\mathrm{s}_{\mathrm{di}}^{2}=0.06$; Line 11 with $\bar{g}=87.28, \mathrm{~b}_{\mathrm{i}}=1.01$ and the $\mathrm{s}_{\mathrm{di}}^{2}=0.72$, and Line 6 with $\bar{g}=90.78, \mathrm{~b}_{\mathrm{i}}=$ 1.0 and the $\mathrm{s}_{\mathrm{di}}^{2}=0.17$. These genotypes could be useful in barley breeding programs for improve this trait.

Genotypic stability parameters of Tai's (1971) measured the deviation from the linear response in terms of the magnitude of error variance, and proposed partitioning the $\mathrm{G} \times \mathrm{E}$ interaction effect of the $i^{\text {th }}$ genotype into two statistics measures namely linear response to environmental effects $\left(\alpha_{i}\right)$ and the deviation from linearity $\left(\lambda_{\mathrm{i}}\right)$. Accordingly, perfectly stable barley genotypes would not change its performance from one environment to another. This is corresponding to stating that $\alpha_{\mathrm{i}}=-1$ and $\lambda_{\mathrm{i}}=1$. Because perfectly stable barley genotypes probably do not exist, barley breeders will have to be satisfied with the accessible levels of stability, i.e. average stability $\alpha=0.0$ and $\lambda_{i}=1$, below average stability $\alpha_{i}>0$ and $\lambda_{i}=1$ and above average stability $\alpha_{\mathrm{i}}<0$ and $\lambda_{\mathrm{i}}=1$. Table 9 and Fig. 1 show that barley genotypes i.e., G2, G8, G10, G11, G12, G13, G17 and G18 were stable and insignificant for linear response to environmental effects $\left(\alpha_{\mathrm{i}}\right)$, as well as, G2, G3, G4, G7, G10, G12, G13, G15, G17 and G18 for the deviation from linear $\left(\lambda_{\mathrm{i}}\right)$. To clarify, G13 (Line 11) and G17 (Giza 2000) had the best genotypic stability values $(\alpha=0.01$ and 0.09 and $\lambda \mathrm{i}=0.73$ and 0.53 , respectively).

AMMI analysis showed that environments (E), barley genotypes $(\mathrm{G})$ and the $\mathrm{G} \times \mathrm{E}$ interaction mean squares were significant for days to $50 \%$ heading (Table 9). The IPCA scores of barley genotypes in the AMMI and SREG analyses were significant for IPCA1 and IPCA2. Variance components (\%) of the sum of squares varied from $53.01 \%$ for genotypes, $38.87 \%$ for environments and $4.93 \%$ for GEI. IPCA 1 score explained $81.16 \%$ and IPCA 2 had $15.38 \%$ of the total GEI for AMMI models. Also, IPCA 1 score explained $91.85 \%$ and IPCA 2 had $6.89 \%$ of the total GEI for SREG models.

A barley genotype with the smaller AMMI stability value (ASV) is considered as more stable (Lopez, 1990; Kang, 2002). According to the ASV ranking in Table 10 and either Fig. 2, the barley genotypes, G11, G8, G16, G18, G12, and G13 were more stable, they located near the origin and less responsive than the corner barley genotypes. On the contrary, the genotypes G3, G14, G6, G7 and G15, thus they were located far away from the origin.

An ideal barley genotype should have the lowest mean performance for days to $50 \%$ heading and be absolutely stable (i.e., perform the best in all environments). G11 (Line 9) was ideal barley genotype, it had the lowest vector length of the lower barley genotype and with zero GEI, as represented by the arrow pointing to it (Fig. 2).

The angle between the vectors of two environments is related to the correlation coefficient among them. The environments $\mathrm{E}_{2}$, $\mathrm{E}_{3}, \mathrm{E}_{5}$ and $\mathrm{E}_{6}$ were positively correlated because all angles among them were smaller than $90^{\circ}$, while the environments $\mathrm{E}_{1}$ and $\mathrm{E}_{4}$ had negatively correlated with four other environments (Fig. 2).

\section{Plant Height}

The regression coefficient $\left(b_{i}\right)$ of 18 barley genotypes ranged from 0.79 (Line 11) to 1.13 (Giza 123), indicating the genetic variability among barley genotypes in their regression response for plant height (Table 10). The obtained $\left(b_{i}\right)$ values were deviated significantly from unity (bi>1) in Giza 123 and Rihane 3. Therefore they good adapted to favorable environments, whereas, the $\left(b_{i}\right)$ values were significantly less than unity $\left(b_{i}<1\right)$ in Line 11 , hereby this relatively better adapted to low water level as less favorable environment. However, barley genotypes, i.e., California mariout, Line 1, Line 2, Line 3, Line 4, Line 5, Line 6, Line 7, Line 8, Line 9, Line 10, Line 12, Line 13, Giza 2000 and Giza 126 had the $\left(b_{i}\right)$ values were not deviated significantly from unity and thus could be grown under wide range of environments (Table 10).

The deviations from regression $\left(\mathrm{S}_{\mathrm{di}}^{2}\right)$ for plant height ranged from 0.19 (Giza 123) to 7.44 (Line 8). The stable barley genotypes with lowest $\mathrm{S}_{\mathrm{di}}^{2}$ values were Giza 123, Line 5, Line 6, Rihane 3 and Giza 2000. The unstable genotypes with the highest and significant $S^{2}{ }_{\text {di }}$ values were Line 1 and Line 8 . The best stable genotypes according to phenotypic stability for plant height were Line 6 with a mean performance across 


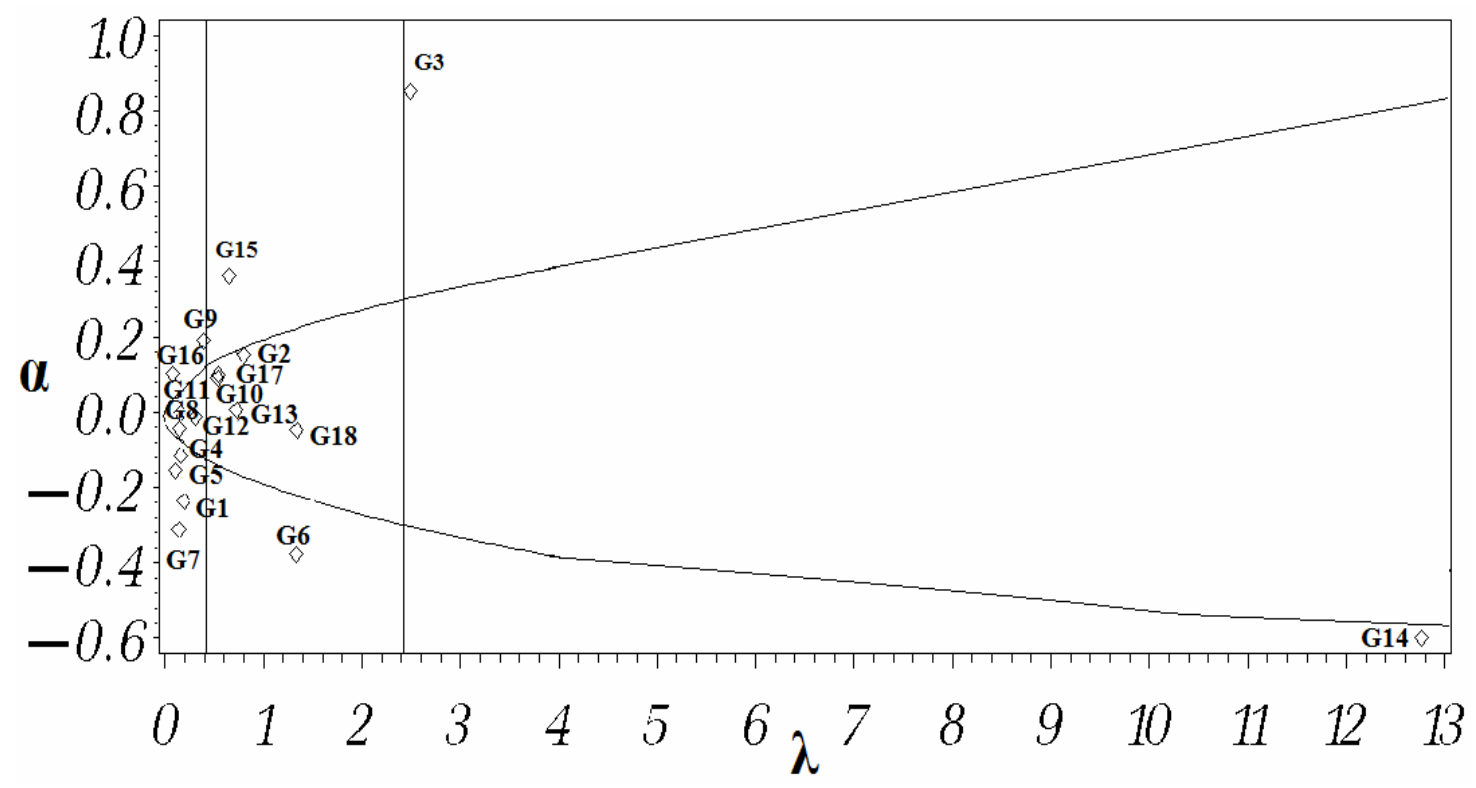

Fig. 1. Genotypic stability parameters ( $\alpha$ and $\lambda$ ) of 18 barley genotypes for days to $50 \%$ heading
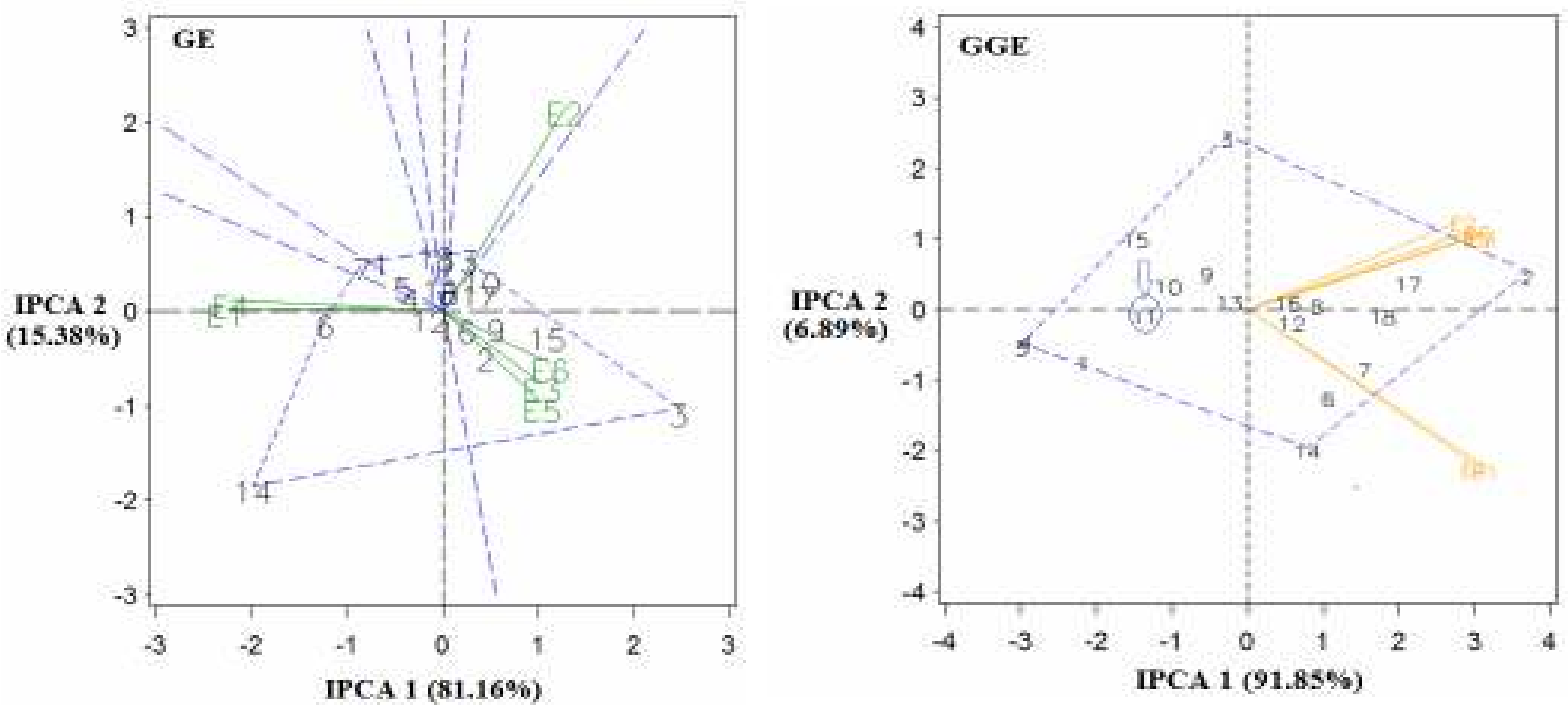

Fig. 2. Graphics display of the GE and GGE biplots for 18 barley genotypes (assessed G1 G18) and six environments (assessed E1- E6) in the AMMI and SREG models, respectively for days to $50 \%$ heading 
environments $\bar{g}=52.86, \mathrm{~b}_{\mathrm{i}}=0.97$ and the $\mathrm{S}_{\mathrm{di}}^{2}=$ 0.93 , followed by Line $5\left(\bar{g}=56.53, b_{i}=1.05\right.$ and $\left.\mathrm{Sd}_{\mathrm{i}}^{2}=0.80\right)$, then Giza $2000\left(\bar{g}=55.53, \mathrm{~b}_{\mathrm{i}}\right.$ $=1.04$ and $\mathrm{S}_{\mathrm{di}}^{2}=0.84$ ).

Regarding genotypic stability parameters, (Table 10 and Fig. 3) showed that all barley genotypes were stable and insignificant for linear response to environmental effects $\left(\alpha_{i}\right)$ except Giza 123, Line 11 and Rihane 3 and also for the deviation from linear $\left(\lambda_{\mathrm{i}}\right)$ except Giza 123, Line 5, Line 6, Line 7, Rihane 3, Giza 2000 and Giza 126. This suggests that California mariout, Line 2, Line 3 and Line 10 had the best genotypic stability values.

AMMI analysis showed that environments (E), barley genotypes $(G)$ and the $G \times E$ interaction mean squares were significant for plant height (Table 9). The IPCA scores of a barley genotype in the AMMI and SREG analyses were significant for IPCA1 and IPCA2. Variance components (\%) of the sum of squares varied from $9.09 \%$ for barley genotypes, $80.59 \%$ for environments and $2.69 \%$ for GEI. IPCA 1 score explained $50.23 \%$ and IPCA 2 had $35.79 \%$ of the total GEI for AMMI model. While for SREG model, IPCA 1 score exhibited $77.71 \%$ and IPCA 2 had $11.35 \%$ of the total GGEI (Fig. 4).

According to the ASV ranking Table 9 and either Fig. 4, the barley genotypes, Line 6 (G8), Line 5 (G7), Line 10 (G12), Line 7 (G9) and Line 2 (G3) were more stable, these barley genotypes were located near the origin and had small ASV. On the other hand, the barley genotypes G4, G11, G13, G6, G15, G3, G2 and G10 were unstable for this trait.

As can be seen GGE biplot for the SREG model (Fig. 4) showed that, Line 6 (G8) was ideal genotype for plant height, it had the lowest vector length of the lower barley genotype and with zero GE, as represented by the mark with an arrow pointing to it. The environments $E_{6}$ with $E_{3}$ and $E_{5}, E_{1}$ with $E_{2}$ were positively correlated because all angles among them were smaller than $90^{\circ}$, while the environment $\mathrm{E}_{4}$ had negatively correlated with $\mathrm{E}_{3}$ and $\mathrm{E}_{6}$.

\section{Flag Leaf Area}

Phenotypic stability parameters indicated that, regression coefficient $\left(b_{i}\right)$ for flag leaf area of 18 barley genotypes ranged from -0.09 (Line $6)$ to 1.50 (Line 11) (Table 11). The $\left(b_{i}\right)$ values were deviated significantly from unity $(\mathrm{bi}>1)$ in Line 1, Line 2, Line 3, Line 8 and Line 11 and less than unity $\left(b_{i}<1\right)$ in Line 9 and Giza 126. On the other side, $\left(b_{i}\right)$ values of the other barley genotypes were not deviated significantly from unity, indicating that these genotypes were adapted well under wide range of environments for flag leaf area.

The deviations from regression $\left(\mathrm{S}_{\mathrm{di}}^{2}\right)$ for flag leaf area ranged from 0.08 (Giza 126) to 5.84 (Line 8). All barley genotypes in this study were unstable; they had significant $\mathrm{S}_{\text {di }}^{2}$ values except Giza 126.

Results of genotypic stability parameters (Table 11 and Fig. 5) showed that all barley genotypes were stable and insignificant for linear response to environmental effects $\left(\alpha_{\mathrm{i}}\right)$ except Line 9, Line 11 and Giza 126. Moreover, for the deviation from linear $\left(\lambda_{\mathrm{i}}\right)$, all barley genotypes were unstable and significant except Line 11 and Giza 126.

AMMI analysis revealed that environments (E), barley genotypes (G) and the $G \times E$ interaction mean squares were highly significant for flag leaf area (Table 9). The IPCA scores of barley genotypes in the AMMI and SREG models were significant for IPCA1 and IPCA2. Variance components (\%) of the sum of squares varied from $36.51 \%$ for barley genotypes, $25.65 \%$ for environments and $30.84 \%$ for GEI. IPCA 1 score explained $42.14 \%$ and IPCA 2 had $28.93 \%$ of the total GEI for AMMI model. Moreover, For SREG model, IPCA 1 score exhibited $60.73 \%$ and IPCA 2 had $15.83 \%$ of the total GGEI (Fig. 6).

A barley genotype with least ASV is the most stable, in respect to flag leaf area as given in Table 10 and illustrated in Fig. 6 the barley genotypes G13, G4, G1, G6, G16, G15, G4, G11 and G18 were the most desired and stable genotypes for flag leaf area. Conversely, the vertex barley genotypes G3, G10, G9, G8, G17, G5 and G14 were unstable, they located far away from the origin for this trait and are more responsive to the environmental changes. 


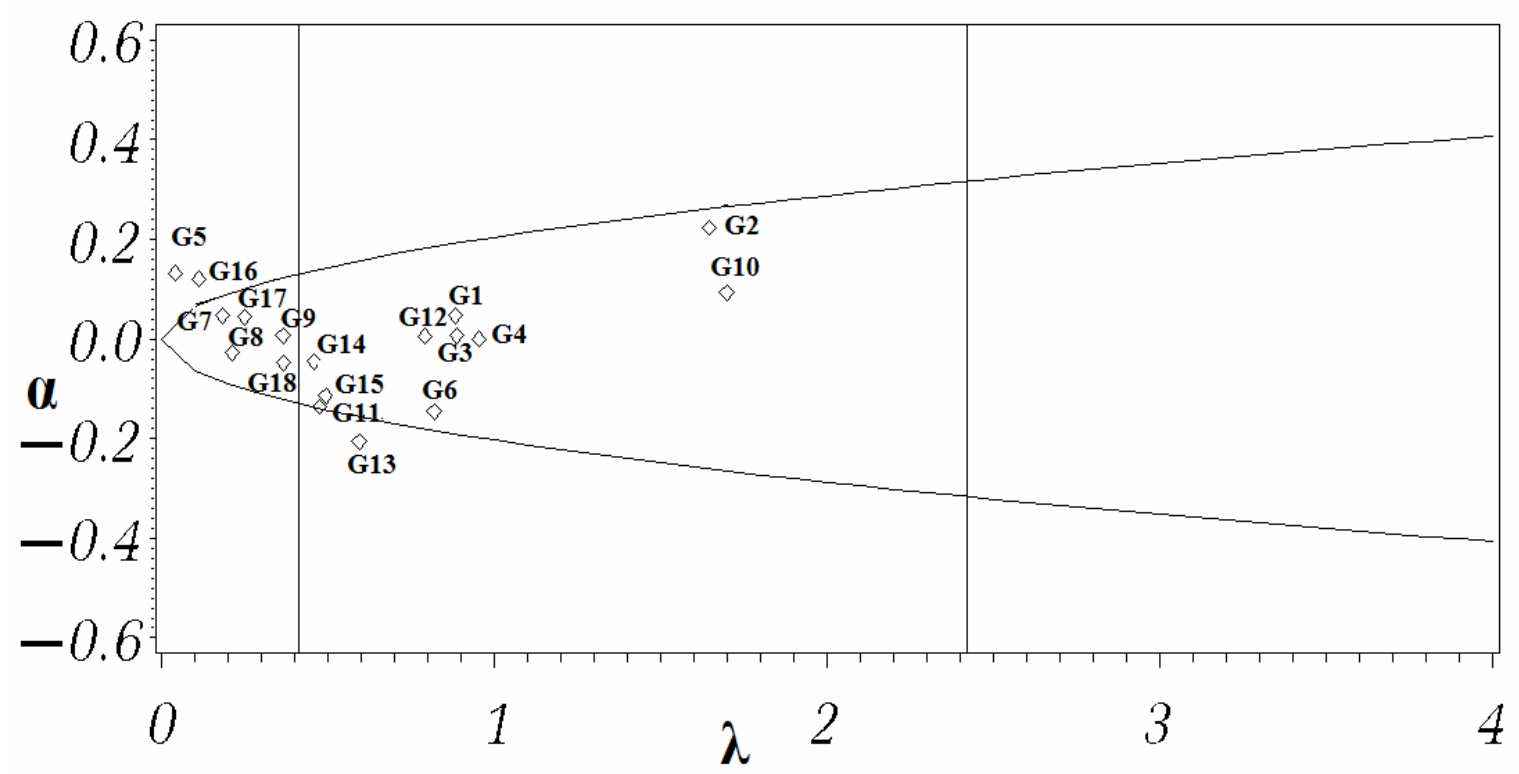

Fig. 3. Genotypic stability parameters ( $\alpha$ and $\lambda$ ) of 18 barley genotypes for plant height
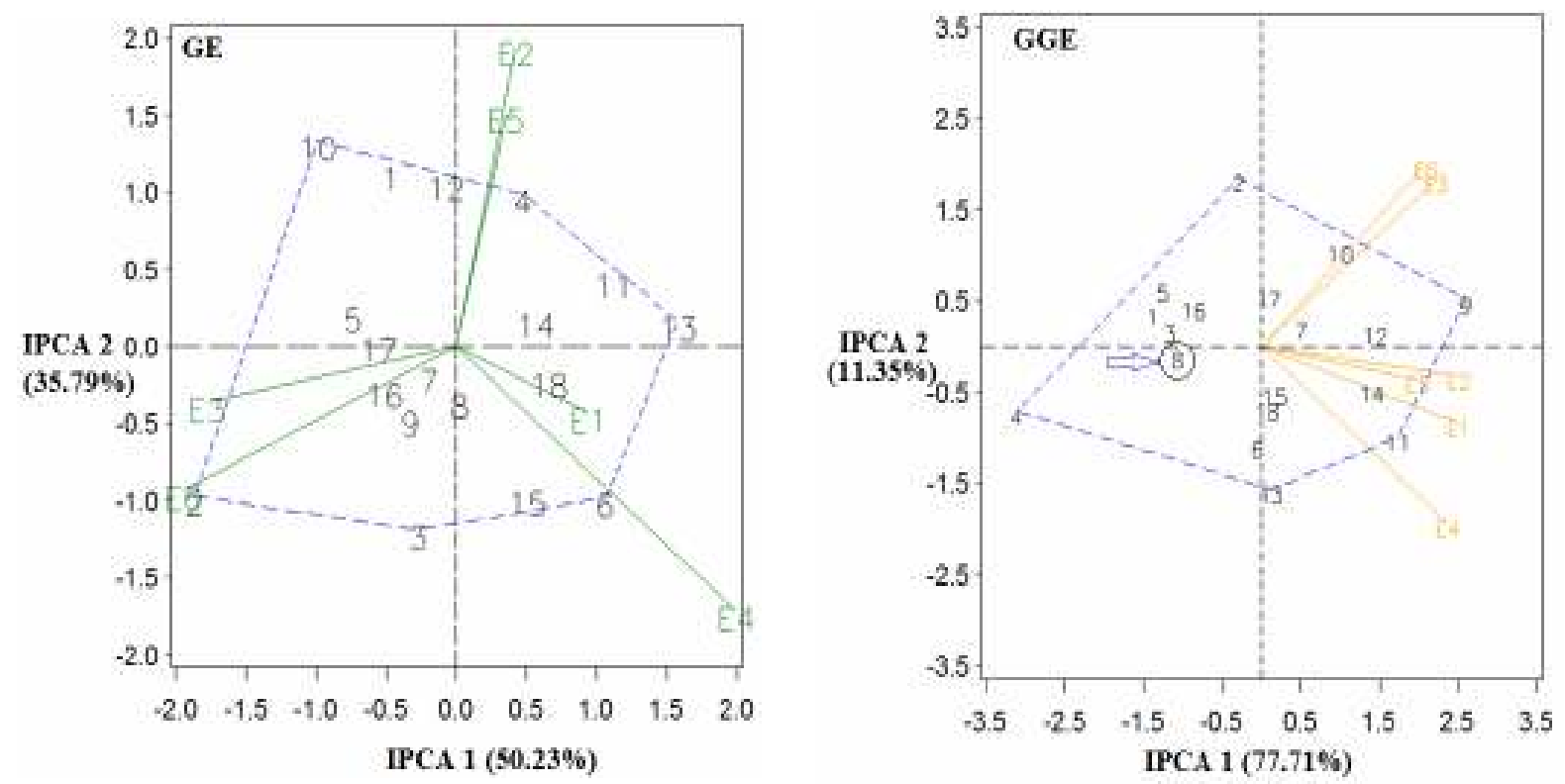

Fig. 4. Graphics display of the GE and GGE biplots of 18 barley genotypes (assessed G1 G18) and six environments (assessed E1-E6) in the AMMI and SREG models, respectively for plant height $(\mathrm{cm})$ 
Table 11. Genotype means over six environments and stability parameters of the eighteen barley genotypes for Flag leaf area and 1000 grain weight

\begin{tabular}{|c|c|c|c|c|c|c|c|c|c|c|c|c|c|c|c|c|}
\hline \multirow{2}{*}{$\begin{array}{l}\text { Traits } \\
\text { Genotype }\end{array}$} & \multicolumn{8}{|c|}{ Flag leaf area $\left(\mathrm{cm}^{2}\right)$} & \multicolumn{8}{|c|}{1000 grain weight (g) } \\
\hline & $\begin{array}{l}\text { Mean } \\
\left.\overline{(\bar{g}}_{i}\right)\end{array}$ & $\overline{\mathbf{P}_{\mathrm{i}}}$ & $\overline{b_{i}}$ & $\mathrm{~S}_{\mathrm{di}}^{2}$ & $\overline{\alpha_{i}}$ & $\overline{\lambda_{\mathrm{i}}}$ & $\overline{A S V}$ & $\overline{\mathbf{R}}$ & $\begin{array}{l}\text { Mean } \\
\left(\bar{g}_{i}\right)\end{array}$ & $\overline{\mathbf{P}_{\mathrm{i}}}$ & $\mathbf{b}_{\mathrm{i}}$ & $\mathbf{S}_{\mathrm{di}}^{2}$ & $\overline{\alpha_{i}}$ & $\overline{\lambda_{i}}$ & $\overline{S V}$ & Rank \\
\hline $\begin{array}{l}1 \text { (California } \\
\text { ariout) }\end{array}$ & 8.86 & 0.76 & 1.05 & $0.95^{* *}$ & 0.05 & $5.85^{*}$ & 0.67 & 2 & 39.92 & 1.49 & $1.58^{* *}$ & 0.50 & $0.60^{*}$ & $0.31^{*}$ & 4.53 & 15 \\
\hline G2 (Line 1) & 10.11 & 2.02 & $1.36^{*}$ & $1.86^{* *}$ & 0.37 & $11.40^{*}$ & 2.32 & 8 & 40.82 & 2.39 & 0.90 & 0.78 & -0.10 & 0.53 & 1.05 & 4 \\
\hline G3 (Line 2) & 9.31 & 1.22 & $1.91^{*}$ & $3.39^{* *}$ & 0.95 & $20.45^{*}$ & 7.14 & 18 & 37.67 & -0.75 & 0.76 & 0.59 & -0.25 & 0.40 & 1.87 & 8 \\
\hline G4 (Line 3) & 7.64 & -0.45 & $1.50^{*}$ & $0.94^{* *}$ & 0.52 & $5.66^{*}$ & 1.44 & 4 & 40.67 & 2.24 & $0.79^{*}$ & 0.08 & $-0.22^{*}$ & $0.05^{*}$ & 1.80 & 6 \\
\hline G5 (Giza 123) & 8.11 & 0.01 & 1.36 & $2.09^{* *}$ & 0.38 & $12.82^{*}$ & 5.28 & 14 & 38.74 & 0.31 & 0.91 & 0.05 & -0.09 & $0.03^{*}$ & 0.85 & 3 \\
\hline G6 (Line 4) & 7.21 & -0.89 & 0.84 & $0.58^{* *}$ & -0.17 & $3.55^{*}$ & 2.69 & 9 & 36.44 & -1.99 & $1.48^{* *}$ & 0.36 & $0.49^{*}$ & $0.22^{*}$ & 3.96 & 13 \\
\hline G7 (Line 5) & 6.29 & -1.81 & 0.43 & $0.73^{* *}$ & -0.60 & $4.32^{*}$ & 3.68 & 12 & 38.85 & 0.42 & $1.57^{* *}$ & 0.43 & $0.59^{*}$ & $0.27^{*}$ & 4.53 & 16 \\
\hline G8 (Line 6) & 7.26 & -0.84 & -0.09 & $2.60^{* *}$ & -1.14 & $15.38^{*}$ & 3.18 & 11 & 38.68 & 0.26 & $1.26^{*}$ & 0.29 & 0.27 & $0.19^{*}$ & 1.86 & 7 \\
\hline G9 (Line 7) & 8.58 & 0.48 & 1.07 & $3.52^{* *}$ & 0.07 & $21.74^{*}$ & 5.37 & 15 & 37.33 & -1.10 & $1.58^{* *}$ & 0.32 & $0.60^{*}$ & $0.19^{*}$ & 4.59 & 17 \\
\hline 10 (Line 8) & 8.71 & 0.62 & $1.48^{*}$ & $5.84^{* *}$ & 0.50 & $35.99^{*}$ & 5.55 & 16 & 37.37 & -1.06 & $0.50^{*}$ & $2.28^{*}$ & -0.52 & 1.53 & 4.13 & 14 \\
\hline G11 (Line 9) & 7.95 & -0.15 & $0.13^{*}$ & $1.21^{* *}$ & $-0.91^{*}$ & $7.02^{*}$ & 0.72 & 3 & 37.74 & -0.69 & 1.20 & 0.95 & 0.21 & 0.64 & 1.92 & 9 \\
\hline G12 (Line 10) & 7.14 & -0.96 & 0.65 & $2.24^{* *}$ & -0.37 & $13.75^{*}$ & 3.96 & 13 & 36.91 & -1.52 & 0.94 & 0.01 & -0.06 & $0.01^{*}$ & 0.38 & 1 \\
\hline G13 (Line 11) & 9.45 & 1.35 & $1.50^{*}$ & $0.33^{*}$ & $0.52^{*}$ & 1.90 & 0.63 & 1 & 39.00 & 0.57 & 1.01 & 0.36 & 0.01 & $0.24^{*}$ & 0.54 & 2 \\
\hline G14 (Line 12) & 9.29 & 1.19 & 1.06 & $4.40^{* *}$ & 0.07 & $27.22^{*}$ & 6.47 & 17 & 38.15 & -0.28 & $0.59^{* *}$ & 0.18 & $-0.42^{*}$ & $0.11^{*}$ & 3.29 & 12 \\
\hline G15 (Line 13) & 8.55 & 0.45 & 0.99 & $0.62^{* *}$ & -0.02 & $3.86^{*}$ & 2.17 & 7 & 38.77 & 0.34 & $-0.18^{* * *}$ & 1.39 & $-1.22^{*}$ & 0.82 & 9.28 & 18 \\
\hline ane 3) & 9.11 & 1.01 & 1.33 & $0.87^{* *}$ & 0.35 & $5.33^{*}$ & 2.08 & 6 & .81 & 1.39 & 1.15 & 0.42 & 0.16 & $0.28^{*}$ & 1.17 & 5 \\
\hline G17 (Giza 2000) & 13.18 & 5.08 & 1.17 & $4.11^{* *}$ & 0.17 & $31.72^{*}$ & 3.16 & 10 & 38.67 & 0.24 & $0.70^{* *}$ & 0.09 & $-0.31^{*}$ & $0.07^{*}$ & 2.39 & 11 \\
\hline G18 (Giza 126) & 9.03 & 0.94 & $0.28^{* *}$ & 0.08 & $-0.75^{*}$ & 0.40 & 2.07 & 5 & 38.27 & -0.16 & $1.26^{*}$ & 0.12 & $0.27^{*}$ & $0.12^{*}$ & 2.29 & 10 \\
\hline $\operatorname{Mean}\left({ }^{\bar{X}}\right)$ & 8.10 & & & & & & & & 38.43 & & & & & & & \\
\hline LSD' 0.05 & 0.39 & & & & & & & & 1.01 & & & & & & & \\
\hline
\end{tabular}

$\overline{\mathrm{g}_{\mathrm{i}}}=$ Mean of genotype, $\left(\mathrm{P}_{\mathrm{i}}\right)=$ Phenotypic index $\left(\overline{\mathrm{g}}_{\mathrm{i}}-\overline{\overline{\mathrm{X}}}\right), \mathrm{b}_{\mathrm{i}}=$ regression coefficient and $\mathrm{S}_{\mathrm{di}}=$ mean square deviations from linear regression, $\alpha_{1}=$ linear response to environmental effects, $\lambda_{\mathrm{i}}=$ the deviation from linear response and ASV $=$ AMMI stability value. $*$,** Significant at 0.05 and 0.01 levels of probability, respectively.

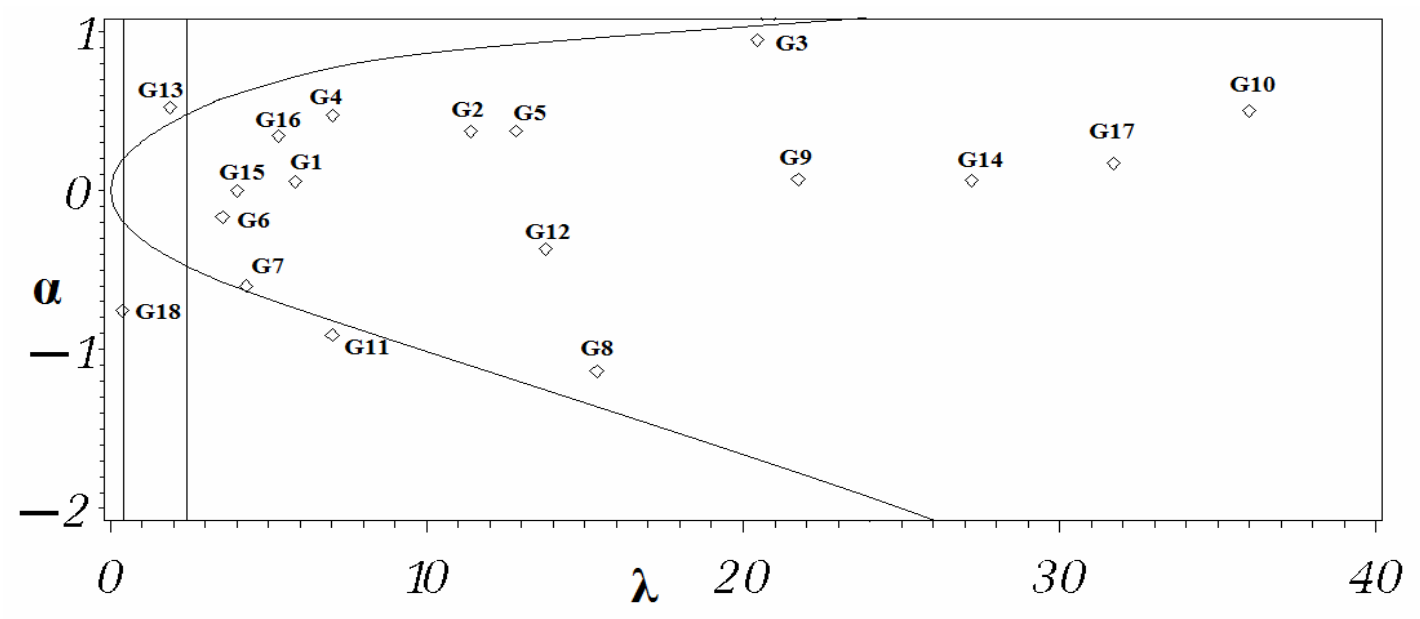

Fig. 5. Genotypic stability parameters ( $\alpha$ and $\lambda)$ of 18 barley genotypes for flag leaf area $\left(\mathrm{cm}^{2}\right)$ 

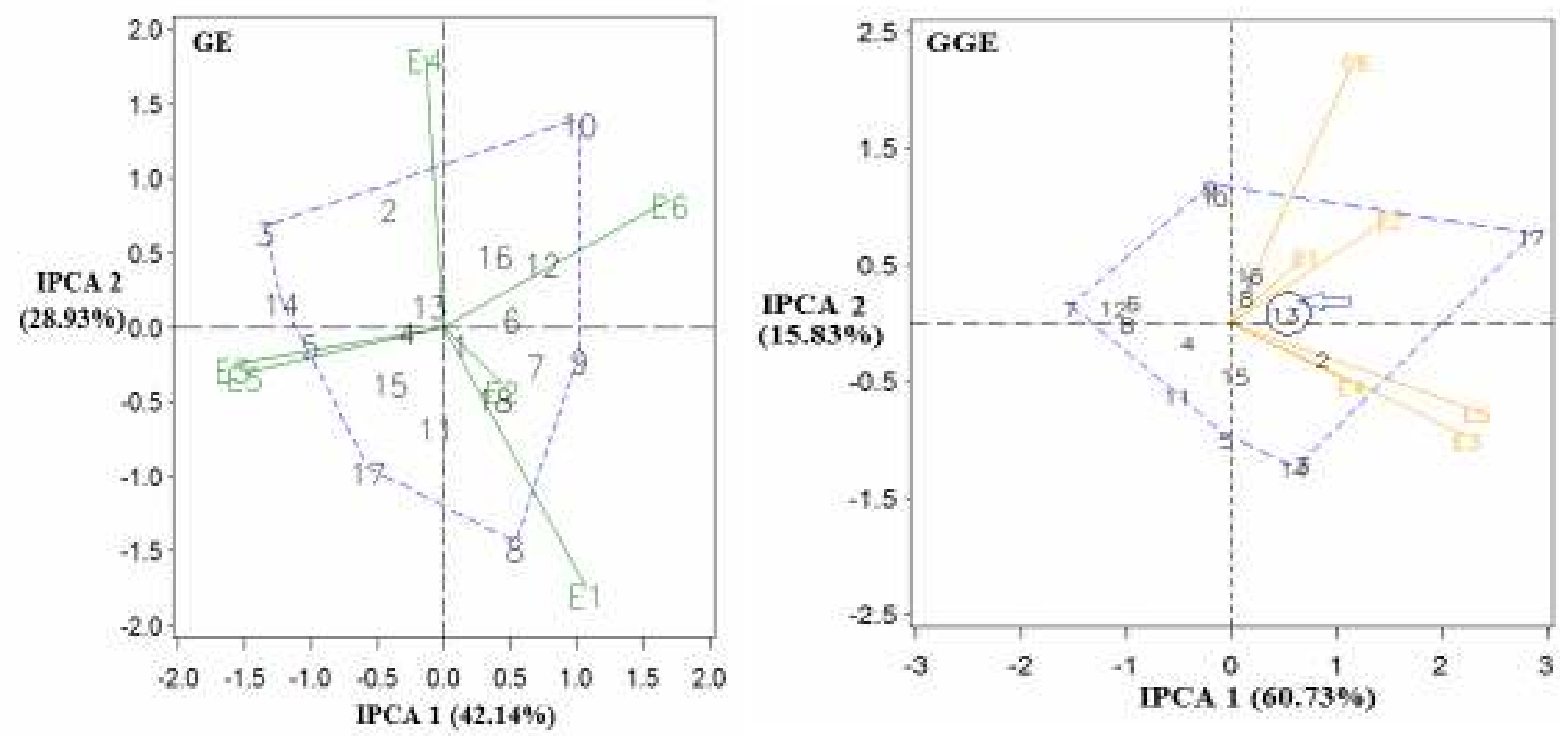

Fig. 6. Graphics display of the GE and GGE biplots of 18 barley genotypes (assessed G1 G18)and six environments (assessed E1- E6) in the AMMI and SREG models, respectively for flag leaf area $\left(\mathrm{cm}^{2}\right)$

GEI biplot graph for the AMMI showed that, Environments $\mathrm{E}_{6}, \mathrm{E}_{1}, \mathrm{E}_{4}$ and $\mathrm{E}_{5}$ were the most differentiating environments for flag leaf area. On the other side, environment $\mathrm{E}_{2}$ was less responsive for this trait.

GGEI biplot graph for the SREG model showed that, G13 (Line 11) was ideal barley genotype for flag leaf area (Fig. 6). Barley genotype G8 was more desirable genotype, this was located closer to the ideal genotype. The environments $E_{5}, E_{4}$ and $E_{3}$ were positively correlated, while the environment $\mathrm{E}_{6}$ had negatively correlated with $\mathrm{E}_{5}, \mathrm{E}_{4}$ and $\mathrm{E}_{3}$.

\section{0-Grain Weight}

Phenotypic stability parameters exhibited that, regression coefficient $\left(b_{i}\right)$ for 1000-grain weight of eighteen barley genotypes ranged from -0.18 (Line 13) to 1.58 (California mariout and line 7), indicating the genetic variability among barley genotypes in their regression response for 1000-grain weight (Table 11). The $\left(b_{i}\right)$ values were deviated significantly from unity (bi>1) in California mariout, line 3, Line 4, Line 5, Line 6, Line 7 and Giza 126 and less than unity $\left(b_{i}<1\right)$ in Line 3 , Line 8 , line 12 , Line 13 and Giza 2000. On the other side, barley genotypes, i.e., Line1, Line 2, Giza 123, Line 9, Line 10, Line 11 and Rihane 3 had the $\left(b_{i}\right)$ values were not deviated significantly from unity, indicating that these barley genotypes were adapted well under wide range of environments for 1000-grain weight.

The deviations from regression $\left(\mathrm{S}_{\mathrm{di}}^{2}\right)$ for 1000-grain weight ranged from 0.01 (Line 10) to 2.28 (Line 8). All barley genotypes in this study were stable, they had lowest $\mathrm{S}_{\mathrm{di}}^{2}$ values and not significantly different from zero except Line 8.

The best stable barley genotypes according the three phenotypic stability parameters $(\bar{g}, \mathrm{bi}$ and $\mathrm{S}_{\mathrm{di}}$ ) for 1000-grain weight were Line 1 (G2), followed by Line 11 (G13), then Rihane 3 and Giza 123. These genotypes gave mean values above grand mean and their regression coefficients $\left(b_{i}\right)$ did not differ significantly from unity with minimum deviation mean squares $\mathrm{S}_{\mathrm{di}}^{2}$, revealing that these barley genotypes were more phenotypic stable.

Results of genotypic stability parameters (Table 11 and Fig. 7) show that 9 out 18 barley genotypes were stable and insignificant for linear response to environmental effects ( $\alpha \mathrm{i})$. Moreover, for the deviation from linear $\left(\lambda_{\mathrm{i}}\right)$, all barley genotypes were unstable and significant except, Line 1, Line 2, Line 8, Line 9 and Line 13.

AMMI analysis showed that environments (E), barley genotypes $(\mathrm{G})$ and the $\mathrm{G} \times \mathrm{E}$ interaction 


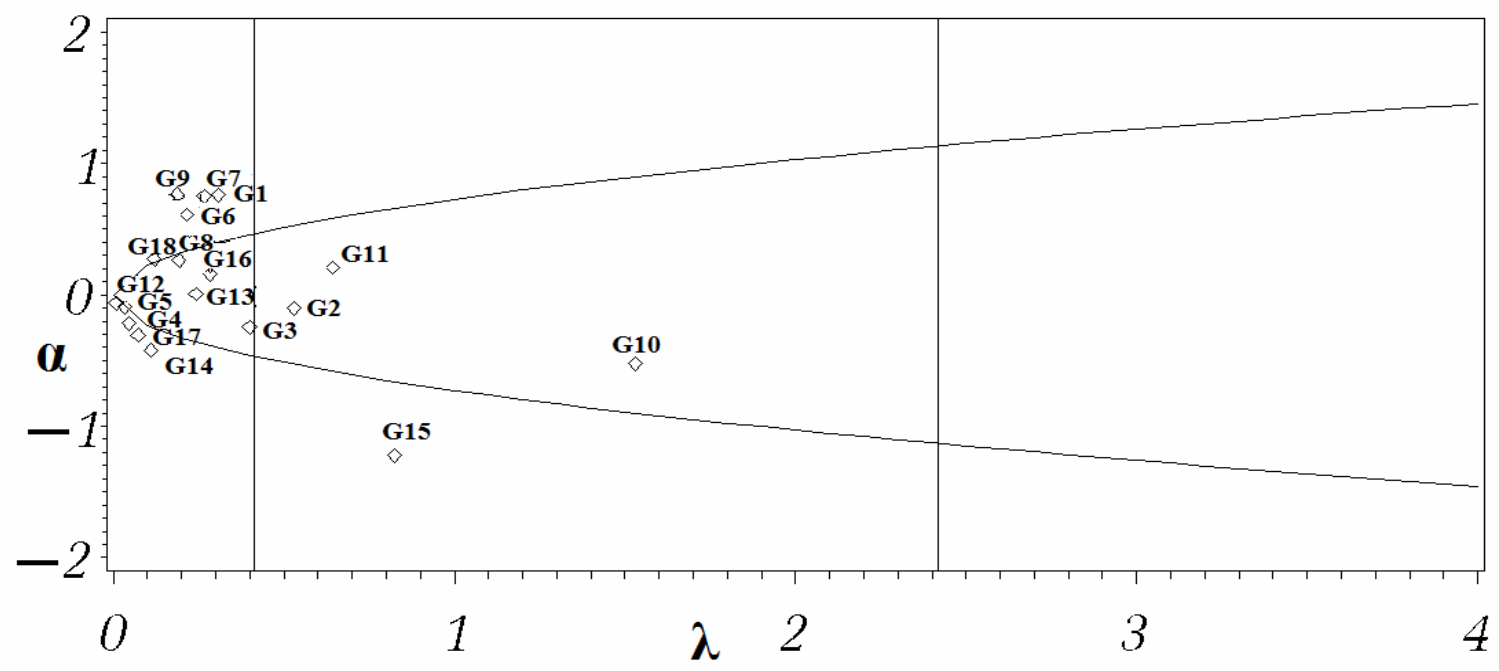

Fig. 7. Genotypic stability parameters ( $\alpha$ and $\lambda$ ) of 18 barley genotypes for 1000 grain weight (g)

mean squares were significant for 1000-grain weight (Table 9). The IPCA scores of barley genotypes in the AMMI and SREG models were highly significant for IPCA1 and IPCA2. Variance components (\%) of the sum of squares valued $19.74 \%$ for barley genotypes, $33.18 \%$ for environments and $11.17 \%$ for GEI. IPCA 1 score explained $69.79 \%$ and IPCA 2 had $28.48 \%$ of the total GEI for AMMI model. Moreover, For SREG model, IPCA 1 score exhibited $64.29 \%$ and IPCA 2 had $24.87 \%$ of the total GGEI.

A barley genotype with least ASV is the most stable, in respect to 1000 -grain weight as given in Table 10 and illustrated in Fig. 8. The barley genotypes i.e., G12, G4, G5, G13 and G16 were the most desired and stable genotypes for this trait, whereas genotypes G18, G8, G14 and G17 were moderate ones. Otherwise, the vertex barley genotypes G15, G10, G1, G7 and G11, were unstable for 1000-grain weight and more responsive to the environmental changes.

GGEI biplot graph for the SREG model (Fig. 8) showed that, Line 1 (G2) was ideal barley genotype for 1000-grain weight, it had the heaviest vector length of the heavier genotype and with zero GEI. Further, barley genotypes G4, G16 and G13 were more desirable genotypes, they were located closer to the ideal genotype. The environments $E_{1}$, with $E_{4} ; E_{2}$ with $E_{5}$ and $E_{3}$ with $E_{6}$ were positively correlated. While the environment
$E_{1}$ and $E_{4}$ had negatively correlated with $E_{3}$ and $\mathrm{E}_{6}$.

\section{Biological Yield (ton/fad.)}

The regression coefficient $\left(b_{i}\right)$ for biological yield of 18 barley genotypes varied from 0.57 to 1.16 for Line 5 and Line 6, respectively (Table 12). The $\left(b_{i}\right)$ values were deviated significantly and less than unity $\left(b_{i}<1\right)$ in Line 4 , Line 5 , Line 12 and Line 13, therefore these barley genotypes were adapted to water defect environments. However, the $\left(b_{i}\right)$ values were deviated significantly and more than unity $\left(b_{i}>1\right)$ in Line 1, Line 3, Line 6, Line 8 and Rihane 3. On the other side, the remaining barley genotypes exhibited regression coefficient values not deviated significantly from unity in California mariout, Line 2, Giza 123, Line 7, Line 9, Line 10, Line 11, Giza 2000 and Giza 126. Hence these genotypes were adapted well under wide range of environments for biological yield (ton/fad.).

The deviations from regression $\left(\mathrm{S}_{\mathrm{di}}^{2}\right)$ for this trait varied from 0.00 (G4 and G15) to 0.13 (G7). All barley genotypes were in this study stable with lowest $\mathrm{S}_{\mathrm{di}}{ }_{\mathrm{di}}$ values and not significantly different from zero except G5, G7 and G12.

Based on the simultaneous consideration of three phenotypic stability parameters $\left(\overline{\boldsymbol{g}}, \mathrm{b}_{\mathrm{i}}\right.$ and $\mathrm{S}_{\mathrm{di}}^{2}$ ) the most desired and stable genotypes were Line $9\left(\bar{g}=4.92, b=1.07\right.$ and $\left.\mathrm{S}_{\mathrm{di}}^{2}=0.06\right)$; Line $7\left(\bar{g}=4.46, \mathrm{~b}=1.00\right.$ and $\left.\mathrm{S}^{2}{ }_{\mathrm{di}}=0.04\right)$ and Line 2 $\left(\bar{g}=4.10, \mathrm{~b}=1.10\right.$ and $\left.\mathrm{S}_{\mathrm{di}}^{2}=0.04\right)$. Obviously, 

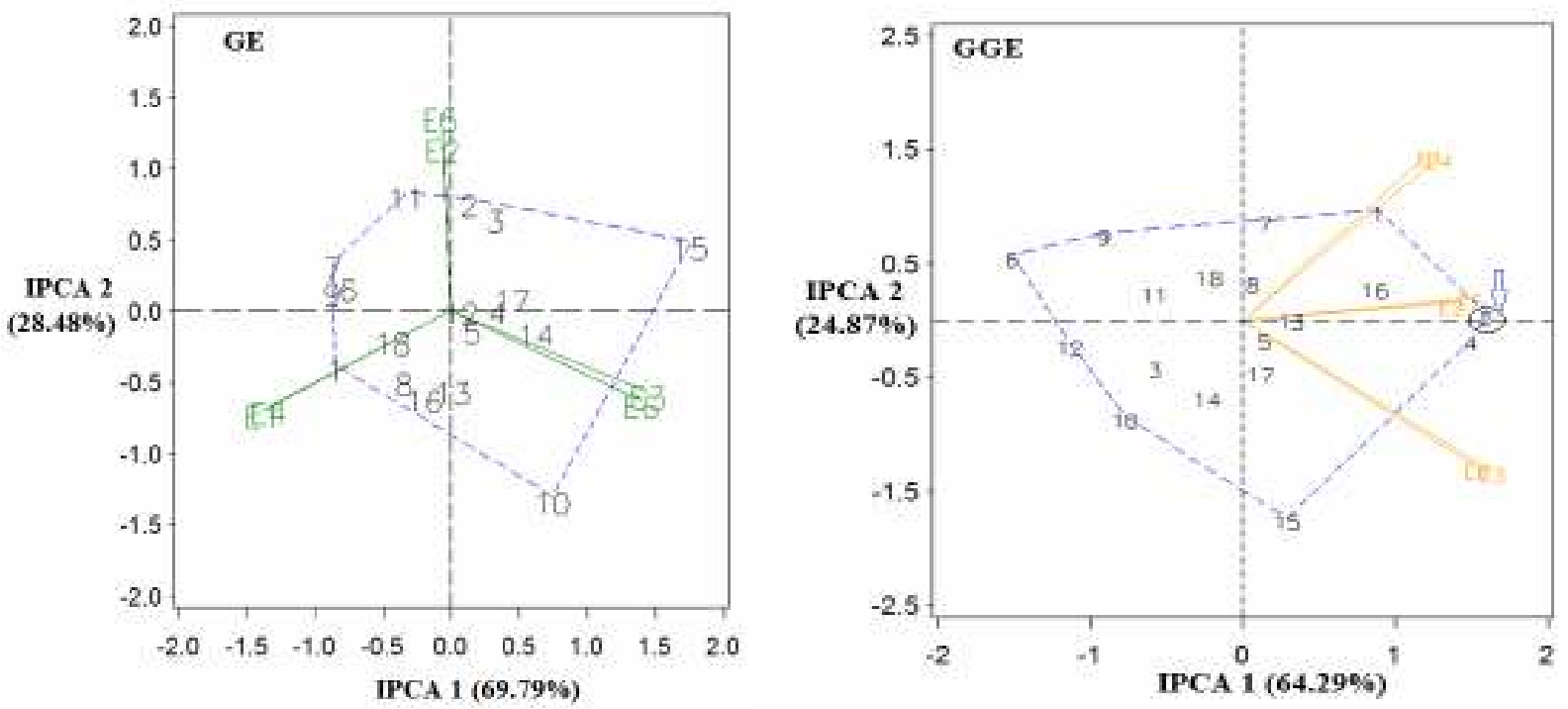

Fig. 8. Graphics display of the GE and GGE biplots of 18 barley genotypes (assessed G1 G18) and six environments (assessed E1- E6) in the AMMI and SREG models, respectively for 1000 grain weight $(g)$

Table 12. Genotype means over six environments and stability parameters of the eighteen barley genotypes for biological yield and grain yield

\begin{tabular}{|c|c|c|c|c|c|c|c|c|c|c|c|c|c|c|c|c|}
\hline \multicolumn{3}{|l|}{ Traits } & \multicolumn{6}{|c|}{ Biological yield (ton/fad.) } & \multicolumn{8}{|c|}{ Grain yield (ardab/fad.) } \\
\hline GeI & $\begin{array}{c}\text { Mean } \\
\left(\bar{g}_{\mathrm{j}}\right)\end{array}$ & $\overline{\mathbf{P}_{\mathbf{i}}}$ & $\overline{\mathbf{b}_{\mathbf{i}}}$ & $\mathbf{S}_{\mathrm{di}}^{2}$ & $\overline{\alpha_{i}}$ & $\overline{\lambda_{i}}$ & $\overline{\mathrm{ASV}}$ & $\overline{\mathbf{k}}$ & $\begin{array}{c}\text { Mean } \\
\left(\overline{\mathrm{g}}_{\mathrm{i}}\right)\end{array}$ & $\overline{\mathbf{P}_{\mathrm{i}}}$ & $\overline{\mathbf{b}_{\mathbf{i}}}$ & $\overline{\mathbf{S}_{\mathrm{di}}^{2}}$ & $\overline{\alpha_{i}}$ & $\overline{\lambda_{i}}$ & $\overline{\mathbf{A S V}}$ & $\overline{\operatorname{Rank}}$ \\
\hline ariout) & 3.85 & -0.66 & 0.93 & 0.09 & -0.07 & 1.90 & 1.16 & 8 & 10.76 & -2.41 & 0.93 & 0.02 & -0.07 & $5^{*}$ & 0.44 & 3 \\
\hline G2 (Line 1) & 4.17 & -0.34 & $12^{*}$ & 0.05 & 0.12 & 0.97 & 1.36 & 12 & 11.75 & -1.42 & 1.03 & 0.03 & 0.03 & $0.09^{*}$ & 0.24 & 1 \\
\hline 3 (Line 2) & 4.10 & -0.41 & 1.10 & 0.04 & 0.10 & 0.75 & 0.68 & 4 & 11.76 & -1.40 & $0.79^{* *}$ & 0.03 & $-0.21^{*}$ & $0.08^{*}$ & 1.94 & 14 \\
\hline G4 (Line 3) & 4.36 & -0.15 & $1.13^{*}$ & 0.00 & $0.13^{*}$ & $0.03^{*}$ & 0.71 & 5 & 12.45 & -0.72 & $0.87^{* *}$ & 0.01 & $-0.13^{*}$ & $0.02^{*}$ & 1.50 & 12 \\
\hline G5 (Giza 123) & 4.10 & -0.41 & 1.02 & $0.10^{*}$ & 0.02 & 2.16 & 2.24 & 16 & 12.17 & -0.99 & 1.10 & 0.05 & 0.10 & $0.13^{*}$ & 0.34 & 2 \\
\hline G6 (Line 4) & 4.90 & 0.39 & $0.87^{*}$ & 0.04 & -0.13 & 0.87 & 0.37 & 3 & 14.43 & 1.27 & 0.96 & $1.06^{* *}$ & -0.04 & $3.01^{*}$ & 4.44 & 17 \\
\hline G7 (Line 5) & 4.74 & 0.23 & $0.57^{*}$ & $0.13^{*}$ & $-0.43^{*}$ & 2.64 & 3.84 & 18 & 14.97 & 1.80 & $0.88^{* *}$ & 0.02 & $-0.12^{*}$ & $0.05^{*}$ & 1.36 & 11 \\
\hline e6) & 5.00 & 0.49 & $1.16^{*}$ & 0.03 & 0.16 & 0.70 & 1.28 & 10 & 15.07 & 1.90 & 0.96 & 0.01 & -0.04 & $0.04^{*}$ & 0.56 & 5 \\
\hline e 7) & 4.46 & -0.05 & 1.00 & 0.04 & 0.00 & 0.84 & 0.88 & 7 & 12.91 & -0.25 & 1.05 & 0.07 & 0.06 & $0.20^{*}$ & 0.61 & 6 \\
\hline ine 8) & 4.53 & 0.02 & 1.14 & 0.02 & 0.14 & $0.38^{*}$ & 1.25 & 9 & 13.21 & 0.04 & 0.94 & 0.01 & $-0.06^{*}$ & $0.01^{*}$ & 0.53 & 4 \\
\hline ne 9) & 4.92 & 0.41 & 1.07 & 0.06 & 0.07 & 1.31 & 0.80 & 6 & 14.68 & 1.51 & 1.05 & 0.09 & 0.05 & $0.27^{*}$ & 1.14 & 10 \\
\hline ne 10) & 4.98 & 0.47 & 0.97 & $0.12^{*}$ & -0.03 & 2.53 & 2.28 & 17 & 13.83 & 0.66 & 1.10 & 0.05 & 0.10 & $0.15^{*}$ & 1.12 & 9 \\
\hline (Line 11) & 4.35 & -0.16 & 1.07 & 0.03 & 0.07 & 0.71 & 1.46 & 13 & 12.93 & -0.24 & $0.78^{*}$ & $0.33^{*}$ & -0.22 & 0.93 & 0.88 & 7 \\
\hline ine 12) & 4.44 & -0.07 & $0.83^{*}$ & 0.04 & -0.17 & 0.92 & 0.34 & 2 & 12.07 & -1.10 & $0.76^{* *}$ & 0.07 & $-0.24^{*}$ & $0.19^{*}$ & 2.64 & 16 \\
\hline (Line 13) & 4.01 & -0.50 & $0.89^{*}$ & 0.00 & $-0.11^{*}$ & $0.10^{*}$ & 0.18 & 1 & 11.48 & -1.68 & $1.44^{* *}$ & $0.58^{* *}$ & $0.45^{*}$ & 1.63 & 5.75 & 18 \\
\hline (Rihane 3) & 4.46 & -0.05 & $1.11^{*}$ & 0.04 & 0.11 & 0.74 & 1.31 & 11 & 11.92 & -1.25 & $1.14^{*}$ & 0.09 & 0.14 & $0.24^{*}$ & 1.58 & 13 \\
\hline a 2000) & 3.73 & -0.78 & 0.96 & 0.07 & -0.04 & 1.74 & 2.17 & 15 & 10.89 & -2.28 & 1.04 & 0.22 & 0.04 & 0.78 & 2.18 & 15 \\
\hline & 3.84 & -0.67 & 1.04 & 0.04 & 0.04 & 1.39 & 1.70 & 14 & 10.69 & -2.48 & $1.16^{* *}$ & 0.02 & $0.16^{*}$ & $0.07^{*}$ & 1.11 & 8 \\
\hline & 4.51 & & & & & & & & 13.17 & & & & & & & \\
\hline LSD' 0.05 & 0.21 & & & & & & & & 0.39 & & & & & & & \\
\hline
\end{tabular}

$\overline{\mathrm{g}_{\mathrm{i}}}=$ Mean of genotype, $\left(\mathrm{P}_{\mathrm{i}}\right)=$ Phenotypic index $\left(\overline{\mathrm{g}_{\mathrm{i}}}-\overline{\overline{\mathrm{X}}}\right), \mathrm{b}_{\mathrm{i}}=$ regression coefficient and $\mathrm{S}_{\mathrm{d}}^{2}=$ mean square deviations from linear regression, $\alpha_{1}=$ linear response to environmental effects, $\lambda_{\mathrm{i}}=$ the deviation from linear response and ASV $=\mathrm{AMMI}$ stability value. $*$,** Significant at 0.05 and 0.01 levels of probability, respectively. 
these barley genotypes gave mean values above grand mean and their regression coefficients $\left(b_{i}\right)$ did not differ significantly from unity with minimum deviation mean squares $\left(\mathrm{S}_{\mathrm{di}}^{2}\right)$. Accordingly, these genotypes could be useful in barley breeding programs for improving this trait under water defect in newly reclaimed sandy soils.

Genotypic stability parameters given for biological yield in Table 12 and Fig. 9 show that, all barley genotypes were stable and insignificant for linear response to environmental effects $\left(\alpha_{\mathrm{i}}\right)$ except Line 3, Line 5 and Line 13. Moreover, for the deviation from linear $\left(\lambda_{\mathrm{i}}\right)$, all barley genotypes were stable and insignificant except Line 3, Line 8 and Line 13. A simultaneous consideration of the two genotypic stability parameters $\left(\alpha_{\mathrm{i}}\right.$ and $\left.\lambda_{\mathrm{i}}\right)$, the most desired and stable barley genotypes were G3, G9, G11 and G13.

AMMI analysis of variance showed that, environments (E), genotypes $(\mathrm{G})$ and the $\mathrm{G} \times \mathrm{E}$ interaction mean squares were significant for biological yield (Table 9). The IPCA scores of a genotype in the AMMI and SREG analyses were significant for IPCA1 and IPCA2. Variance components $(\%)$ of the sum of squares varied from $18.84 \%$ for genotypes, $65.21 \%$ for environments and $5.69 \%$ for GEI. IPCA 1 score explained $49.83 \%$ and IPCA 2 had $23.82 \%$ of the total GEI for AMMI models. For SREG model, IPCA 1 score explained $80.72 \%$ and IPCA 2 had $10.18 \%$ of the total GGEI.

Based on ASV as given in Table 11 and illustrated in Fig. 10, the barley genotypes G15, G14, G6, G3, G4, G11 and G9 were the most desired and stable genotypes, whereas barley genotypes G9, G10, G16 and G13 were moderate one. Otherwise, the vertex barley genotypes G8, G2, G12, G7, G17 and G18 were unstable for this trait and more responsive to the water stress changes.

GE biplot graph for the AMMI model showed that environments $\mathrm{E}_{6}$ and $\mathrm{E}_{5}$ were the most differentiating environments for biological yield, they were located far away from the origin and they were more responsive to environmental changes (Fig. 10). Conversely, environments $\mathrm{E}_{4}$ and $\mathrm{E}_{3}$ were less responsive for biological yield.
GGE biplot graph for the SREG model showed that, Line 9 (G11) was ideal barley genotype for biological yield (Fig. 10). A barley genotype is more desirable as it is located closer to the ideal genotype, such as G6, G8 and G9. The environments $E_{1}, E_{2}, E_{3}$ and $E_{4}$ were positively correlated. Whereas, the environment $\mathrm{E}_{1}$ was negatively correlated with $\mathrm{E}_{5}$ and $\mathrm{E}_{6}$.

\section{Grain Yield (ardab/fad.)}

Phenotypic stability revealed that, regression coefficient $\left(b_{i}\right)$ for grain yield of 18 barley genotypes ranged from 0.76 (Line 12) to 1.44 (Line 13), indicating the genetic variability among barley genotypes in their regression response for grain yield (Table 12). The $\left(b_{i}\right)$ values were deviated significantly from unity (bi > 1) in Line 13, Rihane 3 and Giza 126, indicating greater sensitivity to environmental changes and were relatively suitable in favorable environments with adequate water and other inputs. Meanwhile, the $\left(b_{i}\right)$ values were deviated significantly and less than unity $\left(b_{i}<1\right)$ in $G 3$, G4, G7, G13 and G14. On the other hand, barley genotypes, i.e., G1, G2, G5, G6, G8, G9, G10, G11, G12 and G16 had the $\left(b_{i}\right)$ values were not deviated significantly from unity, therefore these barley genotypes were adapted well under wide range of environments for grain yield (ardab/ fad.).

The deviations from regression $\left(\mathrm{S}_{\mathrm{di}}^{2}\right)$ for barley grain yield varied from $0.01(\mathrm{G} 4, \mathrm{G} 8$ and G10) to 1.06 (G6). All barley genotypes in this study were stable with lowest $\mathrm{S}_{\text {di }}^{2}$ values and not significant except G6, G13 and G15.

The desirable and stable barley genotypes according to three stability parameters $\left(\bar{g}, b_{i}\right.$ and $\mathrm{S}_{\mathrm{di}}^{2}$ ) for grain yield were G8 with a mean yield $\bar{g}=15.07, \mathrm{~b}=0.96$ and the $\mathrm{S}_{\mathrm{di}}^{2}=0.01 ; \mathrm{G} 11(\overline{\boldsymbol{g}}=$ $14.68, \mathrm{~b}=1.05$ and $\left.\mathrm{S}_{\mathrm{di}}^{2}=0.09\right)$ and $\mathrm{G} 12(\overline{\bar{g}}=$ $13.83, \mathrm{~b}=1.10$ and $\left.\mathrm{S}_{\mathrm{di}}{ }_{\mathrm{di}}=0.05\right)$. These genotypes gave mean values above grand mean and their regression coefficients $\left(b_{i}\right)$ did not differ significantly from unity, also, minimum deviation mean squares $\left(\mathrm{S}_{\mathrm{di}}^{2}\right)$ were detected.

Genotypic stability parameters given for grain yield in Table 12 and Fig. 11 show that, the most barley genotypes had stable and insignificant for linear response to environmental effects $\left(\alpha_{\mathrm{i}}\right)$ were $\mathrm{G} 1, \mathrm{G} 2, \mathrm{G} 5, \mathrm{G} 6, \mathrm{G} 8, \mathrm{G} 9, \mathrm{G} 11$, 


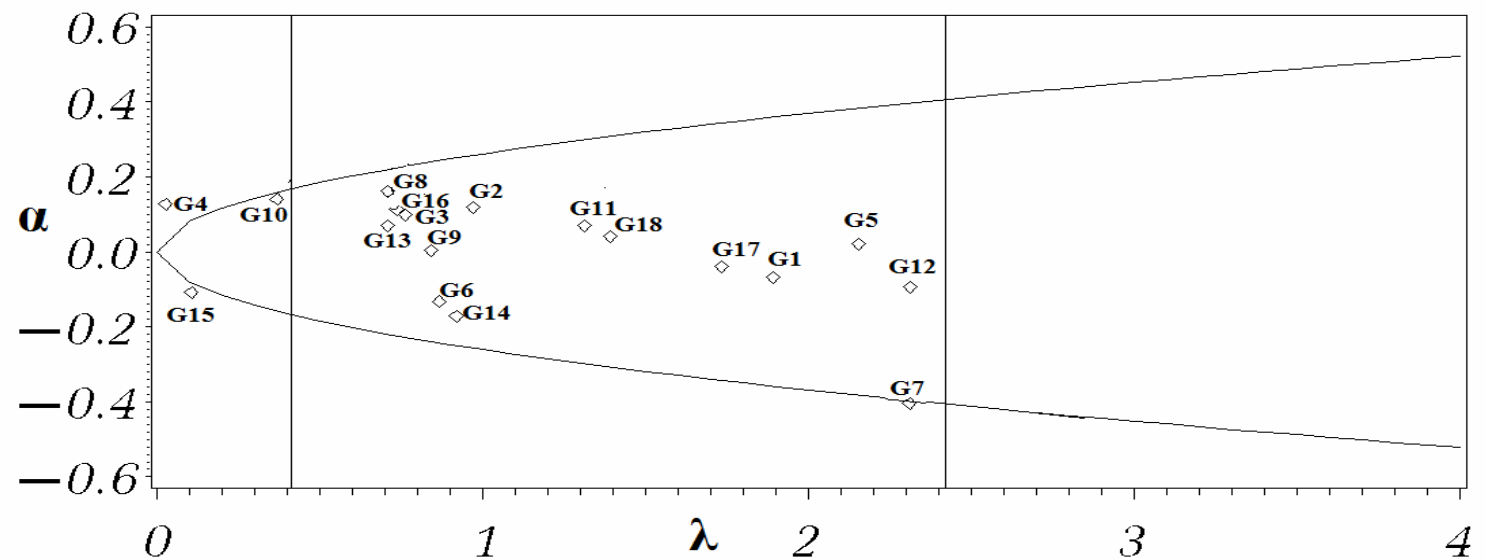

Fig. 9. Genotypic stability parameters $(\alpha$ and $\lambda)$ of 18 barley genotypes for biological yield (ton/fad.)
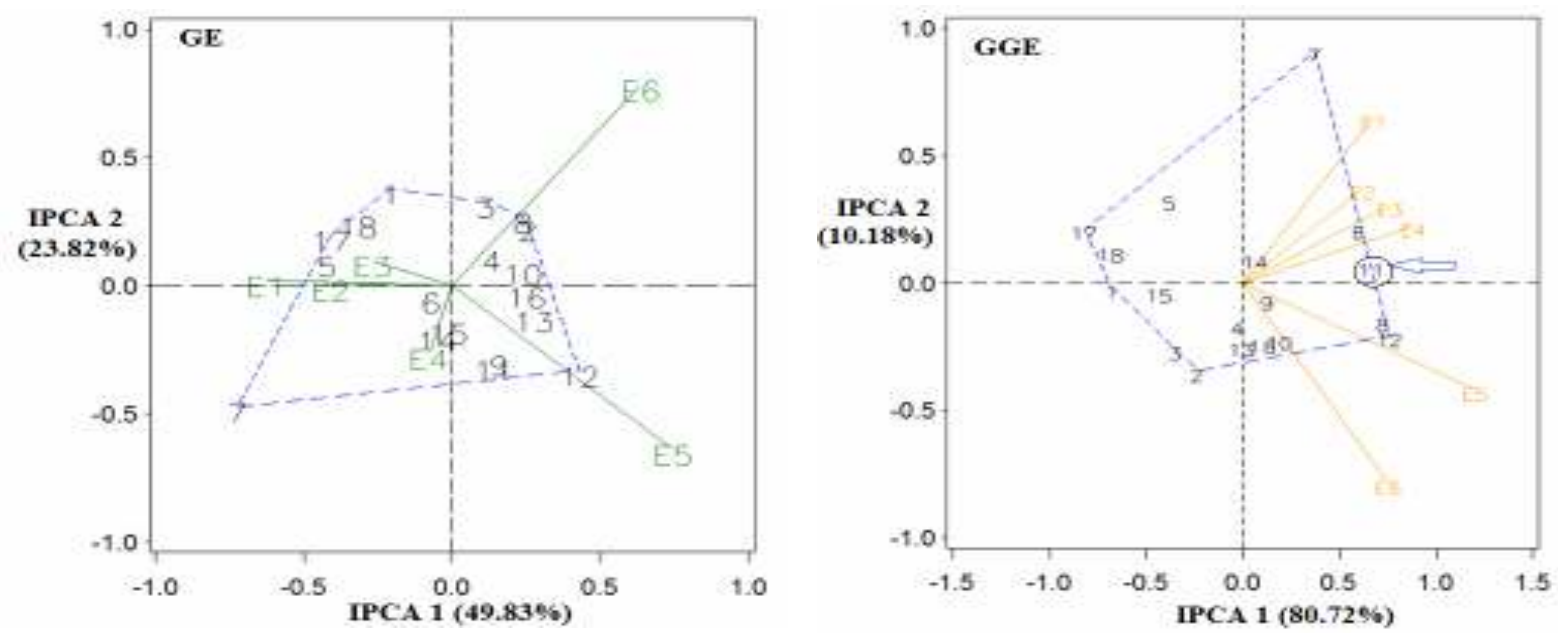

Fig. 10. Graphics display of the GE and GGE biplots of 18 barley genotypes (assessed G1G18) and six environments (assessed E1-E6) in the AMMI and SREG models, respectively for biological yield (ton/fad.)

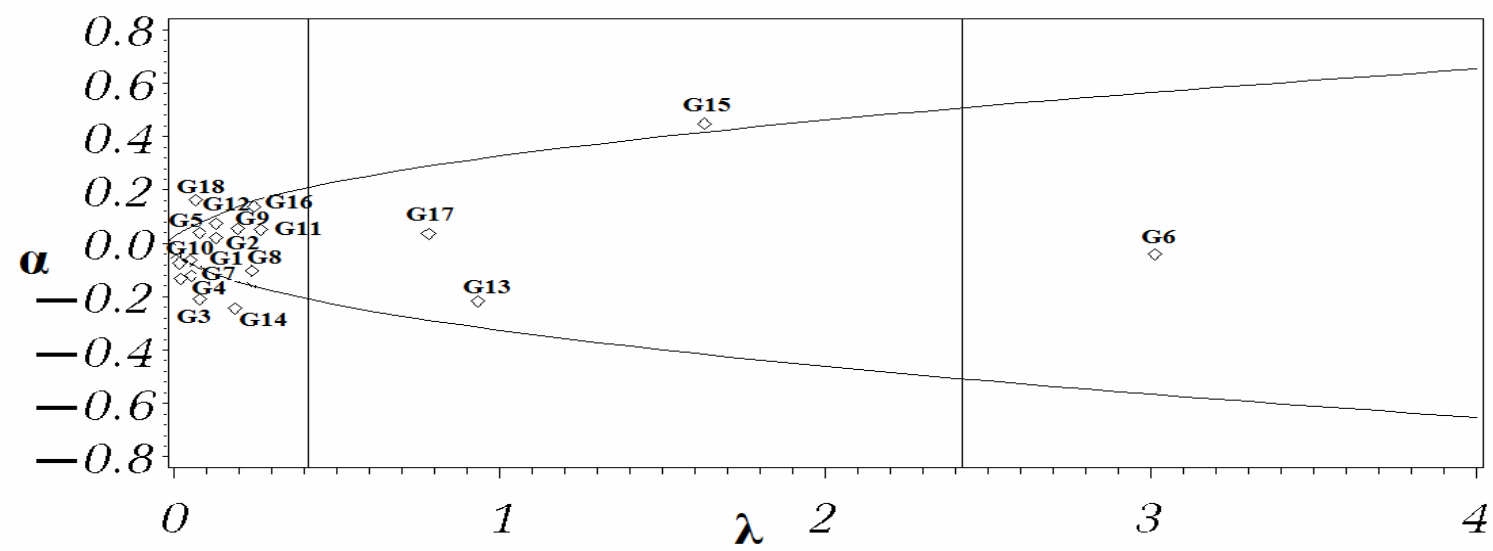

Fig. 11. Genotypic stability parameters ( $\alpha$ and $\lambda$ ) of 18 barley genotypes for grain yield (ardab/ fad.) 
G12, G13, G16 and G17. Moreover, for the deviation from linear $\left(\lambda_{\mathrm{i}}\right)$, all barley genotypes were unstable and significant except G13, G15 and G17.

AMMI analysis of variance showed that environments (E), barley genotypes $(G)$ and the $G \times E$ interaction mean squares were highly significant for grain yield (Table 8). The IPCA scores of a barley genotype in the AMMI and SREG analyses were significant for IPCA1 and IPCA2. Variance components (\%) of the sum of squares varied from $36.55 \%$ for genotypes, $48.56 \%$ for environments and $3.2 \%$ for GEI. IPCA 1 score had $43.91 \%$ and IPCA 2 had $37.84 \%$ of the total GEI for AMMI models. For SREG model, IPCA 1 score exhibited 92.5\% and IPCA 2 had $3.15 \%$ of the total GGEI. Highly significant effects for $G \times$ E interaction for many barley characters were previously reported (Mohammadi et al., 2015; Kendal, 2016; Elakhdar et al., 2017).

A barley genotype with least ASV is the most stable, in respect to grain yield as given in (Table 12) and illustrated in (Fig. 12). The barley genotypes G2, G5, G1, G10 and G8 were the most desired and stable genotypes $(0.24$, $0.34,0.44,0.53$ and 0.56 , respectively), as

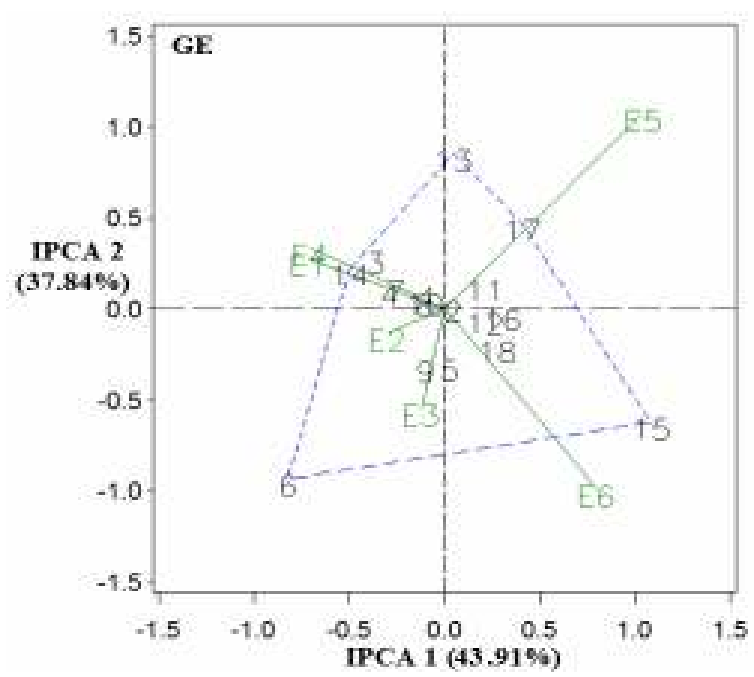

opposed to, barley genotypes G13, G17, G15, G6 and G14 were unstable for this trait and more responsive to the environmental changes.

GE biplot graph for the AMMI model illustrated that, environments $\mathrm{E}_{5}$ and $\mathrm{E}_{6}$ were the most differentiating environments for grain yield, they were located far away from the origin and they were more responsive to environmental changes (Fig. 12). Whereas environments $\mathrm{E}_{2}$ and $E_{3}$ were less responsive for grain yield.

GGE biplot graph for the SREG model as illustrated in (Fig. 12) showed that, G8 (Line 6) was ideal barley genotype for grain yield, it had the highest vector length of the high yielding genotypes and with zero GE, as represented by the dot with an arrow pointing to it in (Fig. 12). A barley genotype is more desirable if it is located closer to the ideal barley genotype, thus G7, G6, G11 and G12 were desirable genotypes. The environments $E_{3}, E_{2}$ and $E_{5}$ were positively correlated. Whereas, the environment $\mathrm{E}_{6}$ had negatively correlated with $\mathrm{E}_{1}$ and $\mathrm{E}_{4}$. The ideal test environment was $E_{2}$, it had large IPCA1 scores and small IPCA2 scores. The favorable environment was E5, but the unfavorable ones were severe stress environments $\left(E_{1}\right.$ and $\left.E_{4}\right)$ for grain yield.

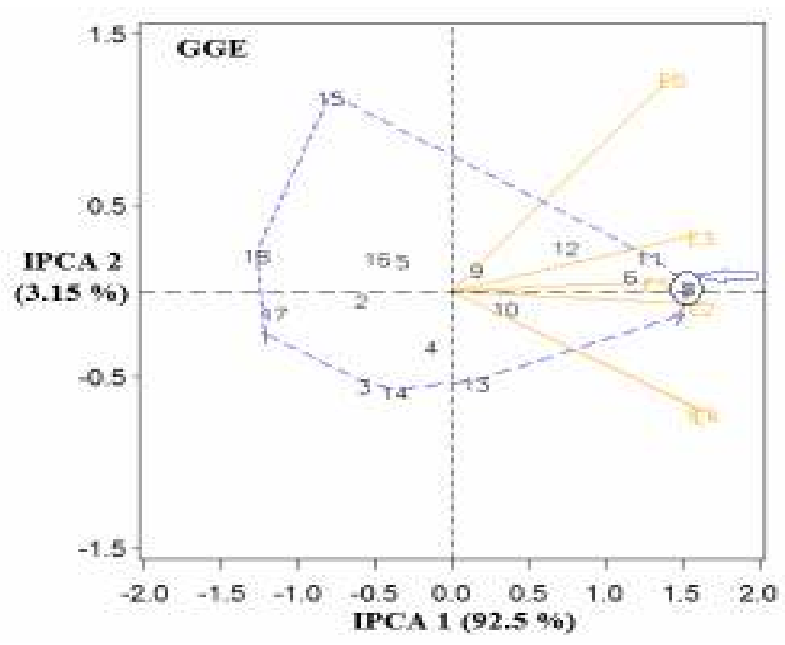

Fig. 12. Graphics display of the GE and GGE biplots of 18 barley genotypes (assessed G1 G18) and six environments (assessed E1- E6) in the AMMI and SREG models, respectively for grain yield (ardab/fad.) 


\section{Conclusion}

Days to $50 \%$ heading (earliness), plant height, flag leaf area and 1000-grain weight are major selection criteria used to develop low soil watery tolerant genotype in newly reclaimed sandy soils.

Accordingly, the three stability methods, i.e. phenotypic stability, genotypic stability and AMMI, the most desired and stable genotypes were Line 9 and Line 11 for days to $50 \%$ heading; Line 6 and Line 5 for plant height; Line 11 and Giza 126 for flag leaf area; Line 1, Giza 123 and Line 11 for 1000-grain weight; Line 9, Line 7 and Line 2 for biological yield (ton / fad.) and Line 6, Line 9 and Line 3 for grain yield ( $\operatorname{ardab} / \mathrm{fad}$. .). These genotypes could be useful in barley breeding programs for improving these traits under water stress in newly reclaimed sandy soils.

Therefore from GGE biplots, the ideal barley genotype was Line 9 for days to $50 \%$ heading; Line 6 for plant height; Line 11 for flag leaf area; Line 1 for 1000-grain weight; Line 9 for biological yield and Line 6 for grain yield. These genotypes had the most suitable under wastes stress and drought conditions.

\section{REFERENCES}

Al-Ajlouni, Z.I., A.M. Al-Abdallat, A.A. AlGhzawi, J.Y. Ayad, J.M. Abu Elenein, N.A. Al-Quraan and P. Stephen Baenziger (2016). Impact of pre-anthesis water deficit on yield and yield components in barley (Hordeum vulgare L.) plants grown under controlled conditions. Agron., 6 (33): 1-14.

Ali, M.M.A. (2016). Estimation of some breeding parameters for improvement grain yield in yellow maize under water stress. J. Pl. Prod., Mansoura Univ., 7 (12): 15091521.

Ali, M.M.A. (2017). Stability analysis of bread wheat genotypes under different nitrogen fertilizer levels. J. Pl. Prod., Mansoura Univ., 8 (2): 261-275.

Ali, M.M.A. and M.I.E. Abdul-Hamid (2017). Yield stability of wheat under some drought and sowing dates environments in different irrigation systems. Zagazig J. Agric. Res., 44 (3): $865-886$.

Baum, M., S. Grando, G. Backes, A. Jahoor, A. Sabbagh and S. Ceccarelli (2003). QTLs for agronomic traits in the Mediterranean environment identified in recombinant inbred lines of the cross 'Arta' 9 H. spontaneum 411. Theor. Appl. Genet., 107:1215-1225.

Blum, A. (1985). Breeding crop varieties for stress environment. CRC Rev. Pl. Sci., 2: 199-238.

Bort, J., A. Febrero, T. Amaro and J.L. Araus (1994). Role of awns in ear water use efficiency and grain weight in barley. Agron., 2: 133-139.

Breese, E.L. (1969). The measurement and significance of genotypes environment interaction in grasses. Heredity, 24: 27-44.

Ceccarelli, S., S. Grand and J. A. G. Van Leur (1987). Genetic diversity in barley landraces from Syria and Jordan. Euphitica 36: 389405.

Chand, N., S.R. Vishwakarma, O.P. Verma and M. Kumar (2008). Phenotypic stability of elite barley lines over heterogeneous environments. Barley Genet. Newsletter, 38: 14-17.

Diab, A.A., B. Teulat-Merah, D. This, N.Z. Ozturk, D. Benscher and M.E. Sorrells (2004). Identification of drought-inducible genes and differentially expressed sequence tags in barley. Theor. Appl. Genet, 109: 1417-1425. DOI: 10.3923/ajcs.2016.43.51

Eberhart, S.A. and W.W. Russell (1966). Stability parameters for comparing varieties. Crop Sci., 6: 36 - 40.

Elakhdar, A., T. Kumamaru, K.P. Smith, R.S. Brueggeman, L.J.A. Capo-chichi and S. Solanki (2017). Genotype by environment interactions (GEIs) for barley grain yield under salt stress condition. J. Crop Sci. Biotechnol. 20: 193-204. https://doi.org/ 10.1007/s12892-017-0016-0

FAOSTAT (2018). Food and Agricultural Organization Statistical Database. http:// www. fa.org/ faostat / en / \#data/QC 
Feriani, W., S. Rezgui and M. Cherif (2016). Grain yield assessment of genotype by environment interaction of Tunisian doubledhaploid barley lines. J. New Sci., Agric. and Biotechnol., 27(7): 1507-1512.

Finlay, K.W. and G.N. Wilkinson (1963). The analysis of adaptation in a plant-breeding programme. Aust. J. Agric. Res., 14: 742754.

Fleury, D., S. Jefferies, H. Kuchel and P. Langridge (2010). Genetic and genomic tools to improve drought tolerance in wheat. J. Exp. Bot., 61:3211-3222.

Forster, B.P., R.P. Ellis, J. Moir, V. Talamè, M.C. Sanguineti, R. Tuberosa, D. This, B. Teulat-Merah, I. Ahmed, S.A.E.E. Mariy, H. Bahri, M.E.L. Ouahabi, N. ZoumarouWallis, M. El-Fellah and M. Ben Salem (2004). Genotype and phenotype associations with drought tolerance in barley tested in North Africa. Ann. Appl. Biol., 144:157-168.

Gabriel, K.R. (1971). The biplot graphic display of matrices with application to principal component analysis. Biometrika, 58: 453467.

Gauch, H.G. (1992). Statistical analysis of regional trials: AMMI analysis of factorial designs. Elsevier, Amsterdam, Netherlands. 278 p.

Haddadin, M.F. (2015). Assessment of drought tolerant barley varieties under water stress. Int. J. Agric. and Forestry, 5 (2): 131-137.

Hossain, A., J.A. Teixeira da Silva, M.V. Lozovskaya, V.P. Zvolinsky and V.I. Mukhortov (2012). High temperature combined with drought affect rainfed spring wheat and barley in southeastern Russia: Yield, relative performance and heat susceptibility-index. J. Pl. Breed. and Crop Sci., 4 (11): 184-196.

Jackson, M.L. (1973). Soil chemical analysis Prentice Hall of Inchan, Private New Delhi.

Kang, M.S. (2002). Genotype-environment interaction: Progress and Prospects, 221-243. In M.S. Kang (ed.) Quantitative Genetics, Genomics, and Plant Breeding. CABI Publ., Wallingford, Oxon, UK.
Kempton, R.A. (1984). The use of biplots in interpreting variety by environmental interactions. J. Agric. Sci., 103 : 123-135.

Kendal, E. (2016). GGE biplot analysis of multienvironment yield trials in barley (Hordeum vulgare L.) cultivars. Ekin J. Crop Breed. and Genet., 2(1):90-99.

Lai, K.N. and M.S. Subba Rao (1951). A rapid method of leaf area determination. Nat., 167: 72.

Lodhi, R.D., L.C. Prasad, S.S. Bornare, A.H. Madakemohekar and R. Prasad (2015) Stability analysis of yield and its component traits of barley (Hordeum vulgare L.) genotypes in multi-environment trials in the north eastern plains of India. SABRAO J. Breed. Genet., 47 (2): 143-159.

Lopez, J. (1990). Estudio de la base geneetica del contenido en taninos condensadaos en la semilla de las habes (Vicia faba L.). Doctoral dissertation, Cardoba Univ., Spain.

Mir, R.R., M. Zaman-Allah, N. Sreenivasulu, R. Trethowan and R.K. Varshney (2012). Integrated genomics, physiology and breeding approaches for improving drought tolerance in crops. Theor. Appl. Genet 125: 625-645.

Mohammadi, M., A.A. Noorinia, G.R. Khalilzadeh and T. Hosseinpoor (2015). Application of GGE biplot analysis to investigate GE interaction on barley grain yield. Curr. Opin. Agric., 4 (1): 25-32.

Purchase, J.L. (1997). Parametric analysis to describe genotype $\mathrm{x}$ environment interaction and yield stability in winter wheat. Ph. D. Thesis, Agron. Dept., Fac. Free State, Bloemfontein, South Africa.

Purchase, J.L., H. Hatting and C.S. Van Deventer (2000). Genotype x environment interaction of winter wheat (Triticum aestivum L.) in South Africa: II. Stability analysis of yield performance. S. Afr. J. Plant Soil, 17: 101107.

Ramla, D., M.S. Yakhou, N. Bilek, M. Hamou, A. Hannachi, A. Aissat and L. MeklicheHanifi (2016). Grain yield stability analysis 
of barley doubled haploid lines in algerian semi-arid zones. Asian J. Crop Sci., 8: 43-51.

Samarah, N.H. (2005). Effects of drought stress on growth and yield of barley. Agron. Sustain. Dev., 25: 145-149.

Samarah, N.H., A.M. Alqudah, J.A. Amayreh, G.M. McAndrews (2009). The effect of lateterminal drought stress on yield components of four barley cultivars. J. Agron. and Crop Sci., 195 (6): 427-441.

Sánchez-Díaz M., J.L. García, M.C. Antolín and J.L. Araus (2002). Effects of soil drought and atmospheric humidity on yield, gas exchange, and stable carbon isotope composition of barley. Photosynthetica, 40: 415-421.

Serraj, R., C.T. Hash and S.M.H. Rivzi (2005). Recent advances in marker-assisted selection for drought tolerance in pearl millet. Pl. Prod. Sci., 8:334-337. doi: 10.1626/ pps. 8.334.

Shaaban, S.M. (2006). Effect of organic and inorganic nitrogen fertilizer on wheat plant under water regime. J. Appl. Sci. Res., 2 (10): 650-656.

Sharafi S., K. Ghassemi-Golezani, S. Mohammadi, S. Lak and B. Sorkhy (2011). Evaluation of drought tolerance and yield potential in winter barley (Hordeum vulgare L.) genotypes. J. Food, Agric. and Environ., 9: 419-422.

Steel, R.G.D., J.H. Torrie and D.A. Dickey (1997). Principles and Procedures of Statistics: A Biometrical Approach. $3^{\text {rd }}$ Ed. McGraw Hill Book Co. Inc. New York.

Tai, G.C.C. (1971). Genotypic stability analysis and its application to potato regional trials. Crop Sci., 11:184-190.

Yan, W. (2001). GGEbiplot: A windows application for graphical analysis of multi-environment trial data and other types of two-way data. Agron. J., 93: 1111-1118.

Zobel, R.W., M.J. Wright and H.G. Gauch (1988). Statistical analysis of a yield trial. Agron. J., 80: 388-393. 


\section{تحليل الثبات للتراكيب الور اثية للشعير تحت مستويات مختلفة من الإجهاد المائي}

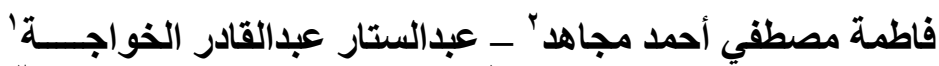

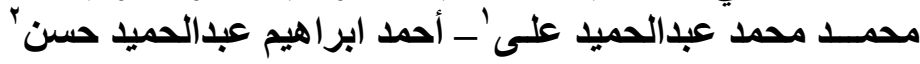

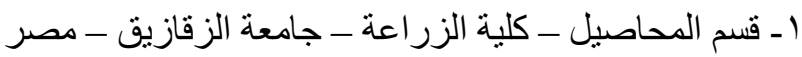

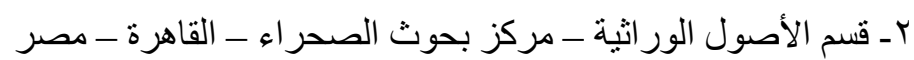

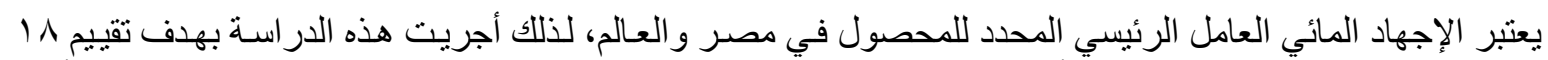

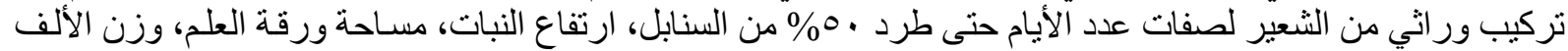

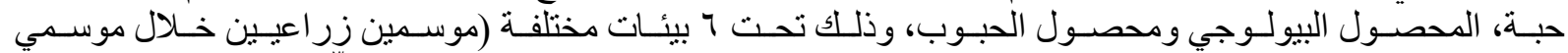

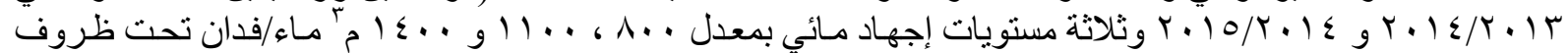

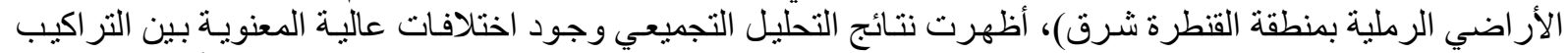

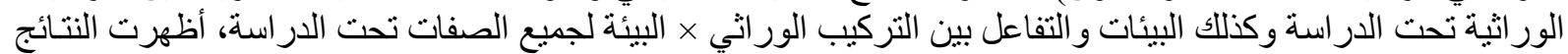

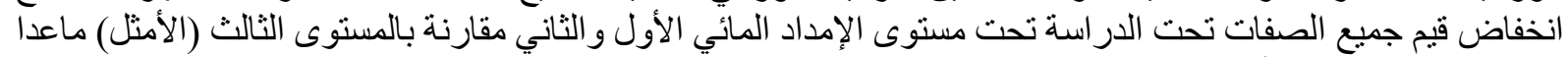

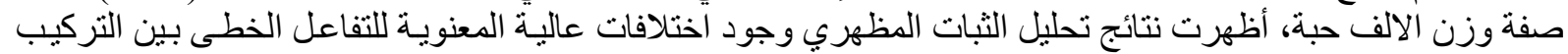

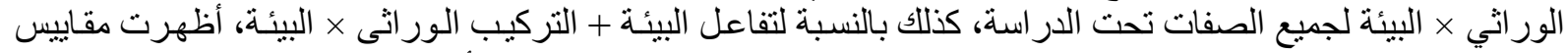

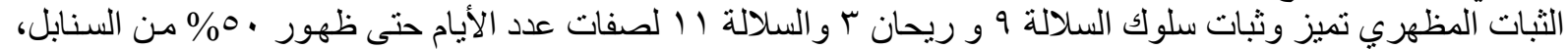

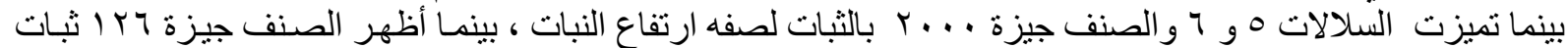

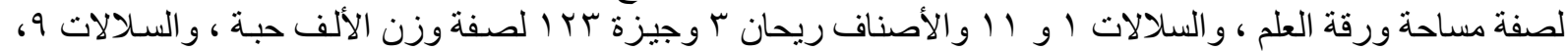

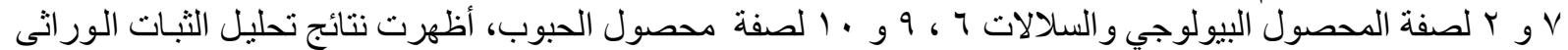

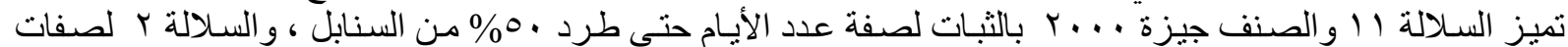

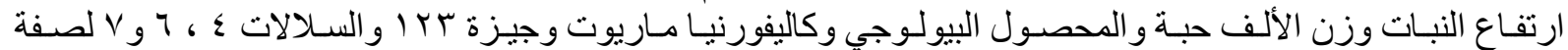

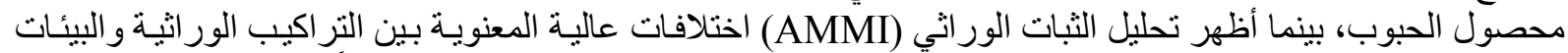

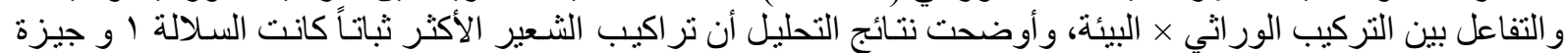

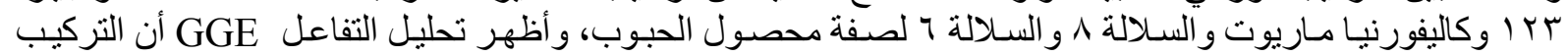

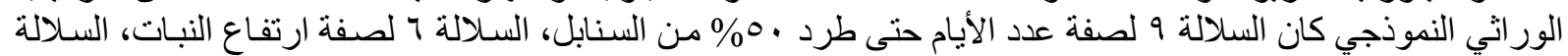

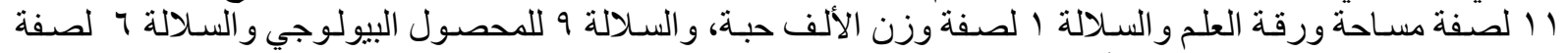

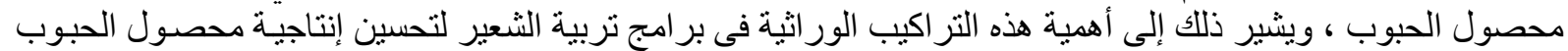
و المحصول البيولوجي تحت ظروف الإجهاد المائي وخاصة بالأر اضي المستصلحة حديثا. 